\title{
Chapter 9 \\ Central Bank of the Republic of Turkey Policy Mix
}

\author{
Mustafa Faruk Aydin and Devrim Yavuz
}

\begin{abstract}
This chapter will focus on the experience of the Central Bank of the Republic of Turkey (CBRT) concerning the policy mix. The chapter discusses the impact of the global financial crisis on the international financial markets, the challenges faced and the need for a policy mix, including how the authorities in Turkey handled the trade-offs, the measures taken and the results.
\end{abstract}

Keywords Policy mix $\cdot$ CBRT $\cdot$ Global financial crisis (GFC)

\section{Introduction}

This chapter will focus on the policy experience of the Central Bank of the Republic of Turkey (CBRT) concerning the policy mix. I work as an economist at the central bank in the Research and Monetary Policy Department. My first lecture is about the central bank policy mix experience in Turkey and then I would like to share some research we have done at the central bank on the policy mix.

The first session will be in three parts. In the first part, I will explain the impact of the global financial crisis on the international financial markets, including the lessons learned, the challenges faced and the need for a policy mix. In the second part, I will explain Turkey's experience concerning the policy mix, how the authorities in Turkey handled the trade-offs, the measures taken and the results. In the last part, I will talk briefly about the recent developments in Turkey, how the policies have affected the reversal of the global financial cycle and gradual normalization of monetary policy.

\section{Some Lessons Learned Since the GFC}

After the 2007-2009 global financial crisis, the advanced economies implemented unorthodox monetary policy, which triggered vast global liquidity and capital flows

M. F. Aydin $(\varangle) \cdot$ D. Yavuz

Central Bank of The Republic of Turkey, Ankara, Turkey 


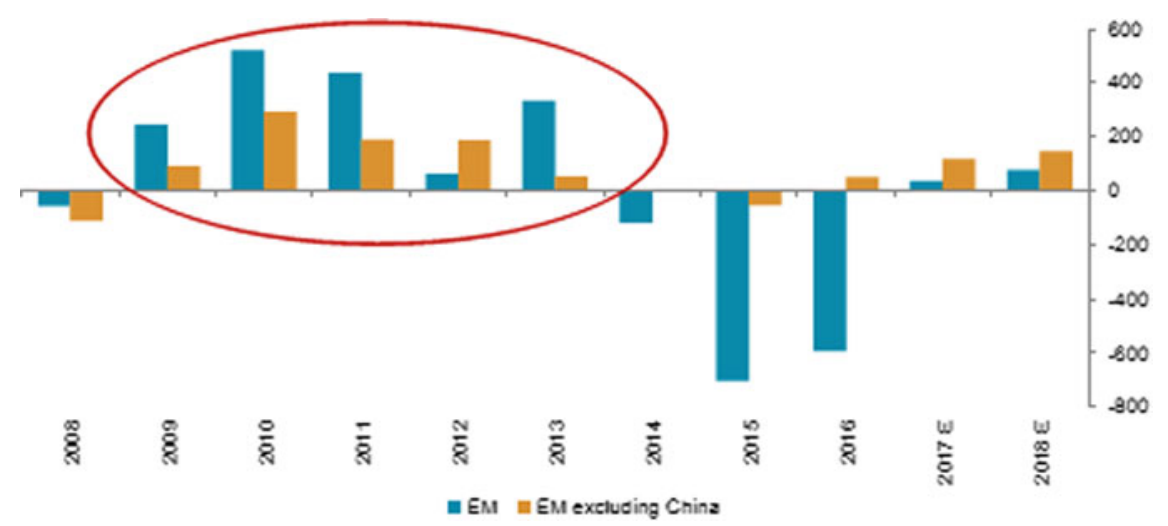

Fig. 9.1 Portfolio flows to emerging markets (net, billion USD). Source IIF

to emerging markets. After the global financial crisis, the unorthodox policies of the advanced economies triggered huge volatility and capital flows to emerging markets. This graph is from the Institute of International Finance (IIF) and shows the portfolio flows to emerging markets. The blue column represents all emerging markets and the orange column represents all emerging markets excluding China. After 2008, we see a huge amount of capital inflows with high volatility. If you want to look at this graph in more detail, we see these volatile capital inflows in bonds and equities. This graph is from the EPFR and it shows that bond and equity flows nearly quadrupled after the QE policies of the advanced economies (Fig. 9.1).

\section{Post-crisis Dynamics and Spillovers to the EMES}

In advanced economies, there were historically low policy rates and quantitative easing policies, which had important implications for emerging markets, such as a surge in capital inflows to emerging markets, rapid credit expansion and real exchange rate appreciation. Consequently, with rapid credit expansion and real exchange rate appreciation, we saw a deteriorating current account balance in the emerging markets. Current account deficits increased vulnerability to sudden stops in global risk appetite and capital flow reversals. Such global financial conditions also amplified macrofinancial linkages in the economy.

\section{A Self-feeding Cycle Amplifies the Effects of Capital Inflows}

Figure 9.2 explains the macro-financial linkages through global liquidity conditions. When global liquidity conditions become easier, it reflects itself as capital inflows to 


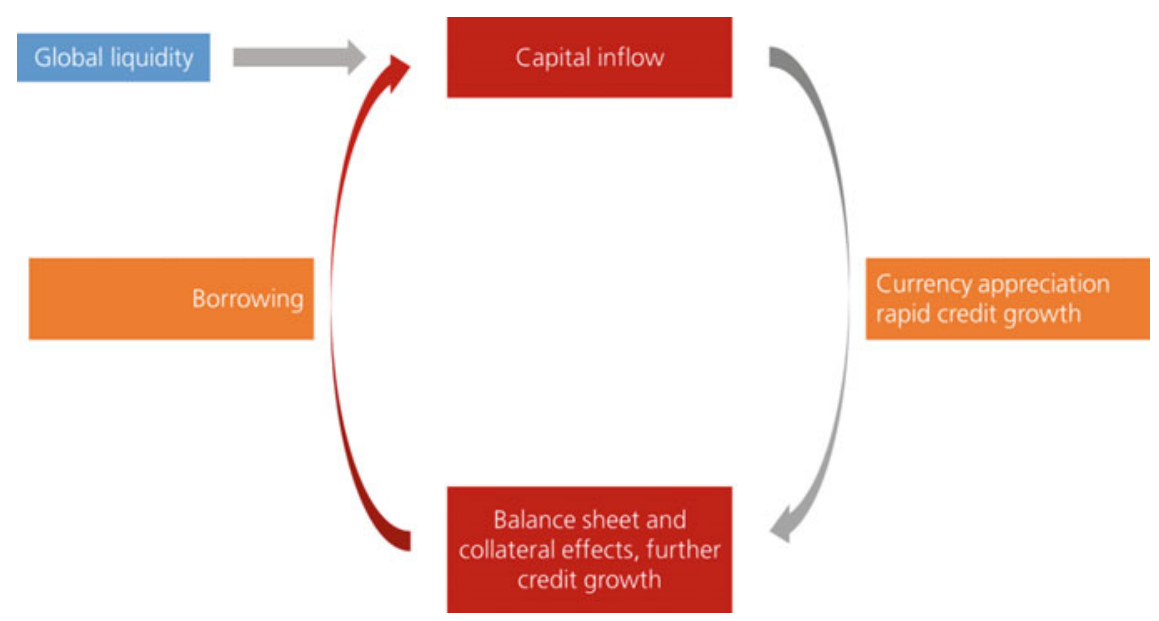

Fig. 9.2 Macro-financial linkages: global liquidity

emerging markets. When the capital inflows come to the emerging countries, we see real currency appreciation and rapid credit growth. Currency appreciation has balance sheet and collateral effects because firms that have foreign currency liabilities on their balance sheet will be in a better position due to currency appreciation. Therefore, the collateral constraints will be relaxed due to real currency appreciation and the firms will demand more credit because they are in a better position. This will lead to further credit growth. To meet the firms' credit demand, banks need to take some external borrowing, which also increases capital inflows. This is a self-feeding cycle and the capital flows amplify the effects of the cycle.

Challenge 1: Financial Channel. There is a challenge under these conditions for the policymakers because the exchange rate should act as a shock absorber under free capital mobility and a flexible exchange rate regime. What I mean by shock absorber is that when capital flows increase, this leads to real currency appreciation and this should be reflected in net exports. When the currency appreciates, we see a decrease in net exports but the self-feeding cycle creates some challenges for the economy because it has a financial channel as well. When capital inflows increase and the real exchange rate appreciates, it has a balance sheet effect through the risktaking channel, which leads to an increase in credit growth. This is the opposite of the trade channel. Through the financial channel, the firms want to have fewer credit constraints and through the risk-taking channel, what I mean is that, since the currency is appreciating, banks think that foreign funding is not as risky as previously because global liquidity conditions are easier. Therefore, the banks take more risk when deciding on the loan portfolio, namely to which firms they want to extend loans. Consequently, banks take more risk. These two channels work in opposite directions, which is a challenge for monetary policy because we do not know how output will be affected through these capital inflows. 
Challenge 2: Exchange Rate Pass-Through. The second challenge concerns exchange rate pass-through. As you would expect, capital inflows are primarily associated with economic booms. Under strong aggregate demand conditions, exchange rate passthrough is stronger. With capital inflows, the domestic currency appreciates and the exchange rate pass-through effect will be rapid because this occurs during a boom period. Domestic currency appreciation lowers imported inflation and provides more room for expansionary policy. Inflation and output move in opposite directions if the pass-through effect is strong. What would the central bank do under such conditions? This creates another challenge for the central bank.

\section{Policy Trade-Off Under Standard Inflation Targeting}

When global liquidity shocks dominate, using a single instrument under ITF may exacerbate the trade-offs. For example, during capital inflows there are two options. The central bank can use the short-term interest rate. If the central bank increases the interest rate, it would lead to further appreciation of the domestic currency and a wider current account deficit, which would make the economy more vulnerable to a sudden stop. Oppositely, if the central bank decreases the interest rate, it would not help to reduce the risk because the move would ease financial conditions thus feeding higher credit growth and over-borrowing in the domestic economy. Therefore, multiple objectives require multiple instruments. The crisis has taught us that to achieve multiple objectives, we need multiple objectives. A single instrument is not enough to achieve our objectives under these global financial conditions.

Benefits and Costs. The use of macroprudential tools entails a trade-off between the benefits and costs. One of the benefits from using macroprudential tools is lower systemic risk, greater resilience as well as lower frequency and severity of crises. Nevertheless, there is an adjustment cost to the financial sector and balance sheet constraints may take time to phase-in. There are also efficiency costs for borrowers from a reduction in the provision of financial services. The final cost is that output growth will vary across tools. For instance, the aggressive tightening of any one single tool can lead to output costs, which implies any tightening should be done gradually. Macroprudential tools should be used gradually to avoid output costs. At the beginning of the crisis, nobody knew how the macroprudential tools would transmit into the economy, which was another cost and challenge for the implementation of macroprudential tools.

\section{Turkey's Policy Mix Experience}

Under such global economic conditions, Turkey's monetary policy has evolved in the past two decades through four distinct periods. In the period from 2001-2005, 
Turkey experienced a domestic crisis. It was a mixture of a balance of payments, banking and fiscal crisis. We saw the adverse consequences of this crisis in the form of declining GDP growth. After the domestic crisis, however, broad-based structural reforms were implemented. We changed the central bank law because in 2001, the central bank was not independent. According to the new central bank law, the central bank gained independence. Before 2001, Turkey implemented a fixed exchange rate regime but after the domestic crisis, we started to implement a flexible exchange rate and changed our monetary policy framework to inflation targeting, beginning with implicit inflation targeting. We did not officially implement the inflation targeting framework because the Turkish economy was not in a strong position after the 2001 crisis. During implicit inflation targeting, we took some actions in terms of the fiscal balance and the banking sector. We established some regulatory and supervisory institutions for the financial markets. This was our preparation period for the official inflation targeting framework.

After 2006, we officially started to implement the full-fledged inflation targeting framework. From 2006 to 2010, we implemented full-fledged inflation targeting in a conventional way, using the short-term interest rates and our objective was price stability. After the global financial crisis and the impact on the financial markets, however, we incorporated financial stability into our inflation targeting framework. From 2011 to April 2016, was our policy mix period because we incorporated financial stability into our policy objectives. Since April 2016 until the present day, we have implemented a monetary policy simplification process.

\section{Inflation in Turkey: 2001-2018}

If you look at the inflation path during these four periods of different monetary policy frameworks, at the beginning, there was a huge crisis in 2001. As a result of structural reforms, there was a long disinflation process during the implicit IT period. After 2006, we implemented full-fledged IT and nearly every year, inflation was above the target. Between the full-fledged IT and policy mix periods, inflation remained above the target but this was acceptable because we did not experience any huge inflation shocks. During the monetary policy simplification process, however, especially during the most recent period, we experienced a huge exchange rate shock that was reflected by an increase in inflation (Fig. 9.3).

\section{Interaction}

Participant: What was your inflation target during this time?

Speaker: $\quad$ Now, it is 5\%. At the beginning, it was around $7 \%$.

Participant: What is the base year? I know that during the crisis last year, there was growth since 2003 but that growth is combined with 


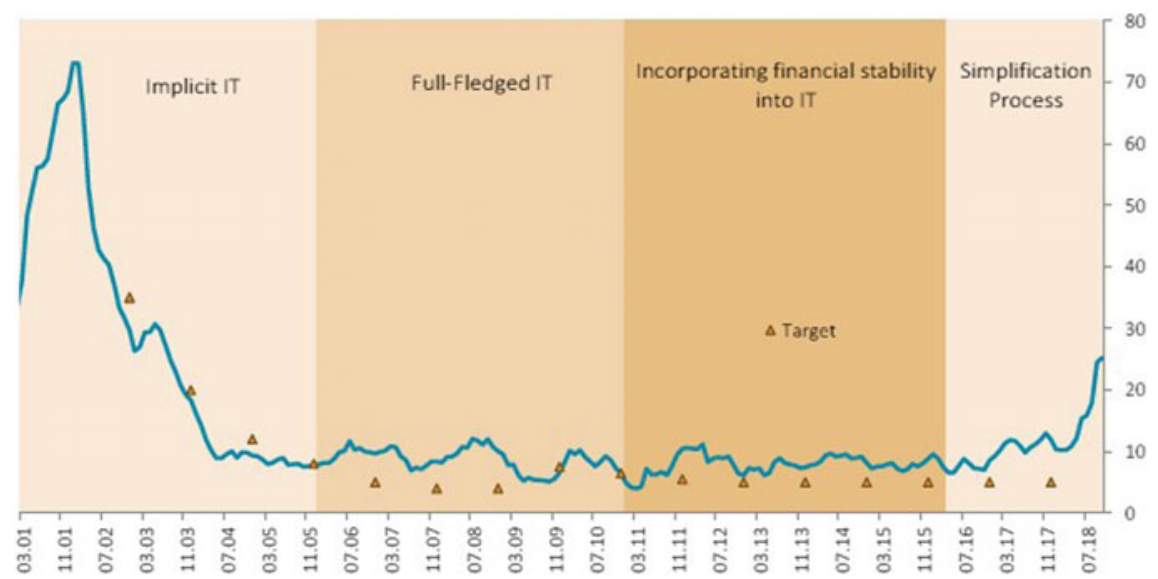

Fig. 9.3 Turkey: inflation. Source TURKSTAT

inflation. There was high growth with high inflation so on the ground we can say there is inflation growth similar to the Asian crisis. I have looked at the Article IV for Turkey and the IMF announced there were high vulnerabilities in 2014 and that growth in Turkey came with high inflation as well, along with a lot of external borrowing. The Central Bank of Turkey would have access to these figures so why was nothing seen before the crisis? There was also something about after the crisis. If there is a crisis in the local currency, I think the first thing you should do is raise the interest rate but this took a long time in Turkey. Another thing is that you said the Central Bank of Turkey is independent but is it not the case that the Minister of Finance still has influence in the central bank? Can the president interfere?

Speaker: $\quad$ No, the central bank is independent. In his speeches, the president is always talking about interest rates but we are trying to distance our policies from his influence. Furthermore, exchange rates pass-through is also high in Turkey.

Participant: I think the central bank did a lot to take into account the vulnerabilities through macroprudential policy but after the Tweet by US President Trump, Turkey experienced a crash.

Speaker: At the beginning, it was also due to political reasons. Therefore, it was rapid to increase but it also decreased rapidly as well. This was an exchange rate shock.

Participant: Since you know that there were vulnerabilities, we should take care about these vulnerabilities and make some macroprudential 


\begin{tabular}{|c|c|}
\hline & $\begin{array}{l}\text { policies to avoid any upcoming crisis but just one Tweet by the } \\
\text { President of the United States triggered a downturn. Why did } \\
\text { CBRT not take this into account? Why was there no action } \\
\text { before the crisis? From Article IV, you can see a large wave } \\
\text { coming, almost like a snowball, getting bigger and bigger, but } \\
\text { there was no action. The actions came a long time after the } \\
\text { crisis. }\end{array}$ \\
\hline Speaker: & $\begin{array}{l}\text { Actually, they did take it into account. The implemented huge } \\
\text { monetary policy tightening and increased the interest rate. After } \\
\text { the monetary policy tightening, the exchange rate started to } \\
\text { appreciate as well but in the beginning, they did not take any } \\
\text { actions because nobody knew what was going on. Some people } \\
\text { were speaking on Twitter and we saw the effect of the Trump } \\
\text { speech on exchange rates. While he was speaking, we saw large } \\
\text { depreciation. Before the crisis, the central bank was trying poli- } \\
\text { cies to contain the adverse effects but you are right, it was not } \\
\text { enough. Some pre-emptive actions could have been taken before } \\
\text { the crisis. It was very hard with the pressure from the president. } \\
\text { We are trying to distance ourselves because we are independent } \\
\text { but it is very difficult to implement policies with such pressures. } \\
\text { The president believes the high interest rate is the reason for high } \\
\text { inflation not that high inflation is the reason for the high interest } \\
\text { rates. He thinks that if the interest rates are high, it will have } \\
\text { some financing costs for the firms and other economic agents, } \\
\text { which leads to an increase in prices. Therefore, there was a lot } \\
\text { of support to decrease interest rates but it is not possible all the } \\
\text { time to do what he suggests. }\end{array}$ \\
\hline Participant: & $\begin{array}{l}\text { Based on the graph, your inflation target was consistently below } \\
\text { actual inflation. Why did you not just increase the target in order } \\
\text { to gain credibility? After you have gained credibility, the central } \\
\text { bank could lower the target again. }\end{array}$ \\
\hline Speaker: & $\begin{array}{l}\text { Actually, we did adjust our target at the beginning of full- } \\
\text { fledged inflation targeting in } 2007-08 \text {. During this period, there } \\
\text { was a huge increase in the oil price so our inflation was also } \\
\text { very high. At the beginning, our medium-term inflation target } \\
\text { was } 4 \% \text { but after the external shocks, we increased the inflation } \\
\text { target to } 5 \% \text {. It is not easy to change the inflation target due } \\
\text { to the negative effects. If you regularly change your inflation } \\
\text { target, the central bank will lose credibility }\end{array}$ \\
\hline Participant: & $\begin{array}{l}\text { What would you do if you do not hit the target at the end of the } \\
\text { year? }\end{array}$ \\
\hline Speaker: & $\begin{array}{l}\text { If we do not hit the target at the end of the year, we have to write } \\
\text { an accountability letter to parliament and the president. There }\end{array}$ \\
\hline
\end{tabular}


was always a reason why we could not hit the target, primarily due to external shocks but food inflation was also very volatile in Turkey, which was another reason we could not hit the target. We did change the target once but to do it too regularly would have negative effects on credibility. Since 2006, our inflation target has remained at $5 \%$. We do have an uncertainty band around the inflation target of $\pm 2 \%$. If inflation remains within the target corridor, we do not have to write an accountability letter to the president and parliament. The change in the target is really hard to explain as we saw in our previous experiences. Also, it is the mid-long- term target for the economy, so if you increase it, there could be negative effects on how the economy will evolve in subsequent periods. The central bank does not want to change the inflation target; they just want to fall within the upper bound. After changing the inflation target once, they did not want to do it again.

Sharp Capital Flow Reversals in Turkey are Associated with Large Output Losses. This graph shows the net capital flows and the GDP growth rate. In Turkey, sharp capital flow reversals are mostly associated with large declines in output growth, or deep recessions. For instance, during the 2001 crisis, the cumulative output loss was around $12.3 \%$ and around $15.1 \%$ during the global financial crisis in 2008-09. This graph clearly illustrates the structural vulnerabilities in the Turkish economy. The savings are insufficient to handle the investment expenditures, so Turkey needs external finance. Therefore, if there is a sudden stop in the capital inflows, we see a sharp recession in the domestic economy (Fig. 9.4).

Rapid Credit Growth and Currency Appreciation after Quantitative Easing. After the global financial crisis, there were huge capital flows to emerging markets, including Turkey. This was reflected in credit growth and also in the exchange rate. Figure 9.5 shows total loan growth in Turkey since the GFC. From the beginning of QE by the Federal Reserve, credit growth started to increase, reaching around $45 \%$ (yoy) by 2010. Figure 9.6 shows the real exchange rate, with $20 \%$ appreciation in one year after QE policy.

Sharp Widening in the Current Account Deficit, Financed with Short-Term Inflows. This surge in capital inflow also showed itself in the current account deficit. The current account deficit in Turkey increased to around 7\% of GDP in that period. The current account deficit was mostly financed by short-term capital inflows. On the right graph, the red bars show portfolio and short-term flows. Most of the current account deficit was financed by unstable portfolio and short-term flows. In our history, we know that if there is a sudden reversal of capital flows, we will see a rapid contraction in the economy. This is not the case only in Turkey but for all emerging markets. Somebody needed to do something under these conditions. At that point, the central 


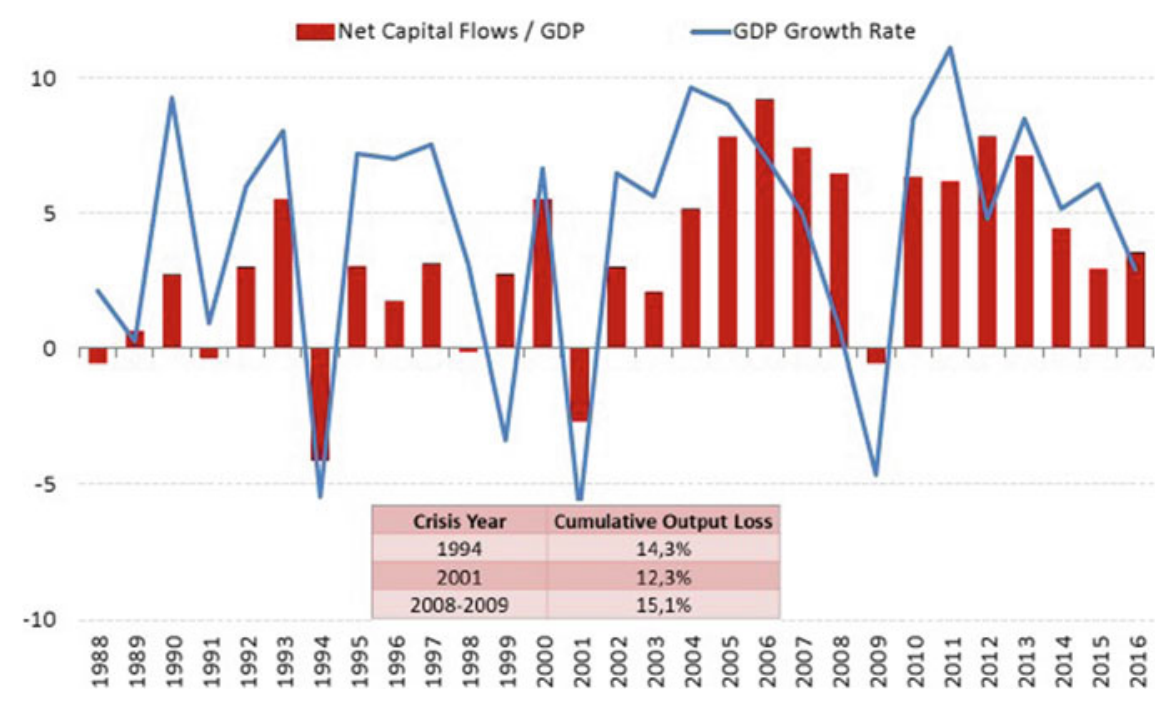

Fig. 9.4 Turkey: capital flows. Source CBRT, TURKSTAT

Fig. 9.5 Turkey: total loans growth (13 weeks moving average, annualized, FX adjusted, percent). Source CBRT

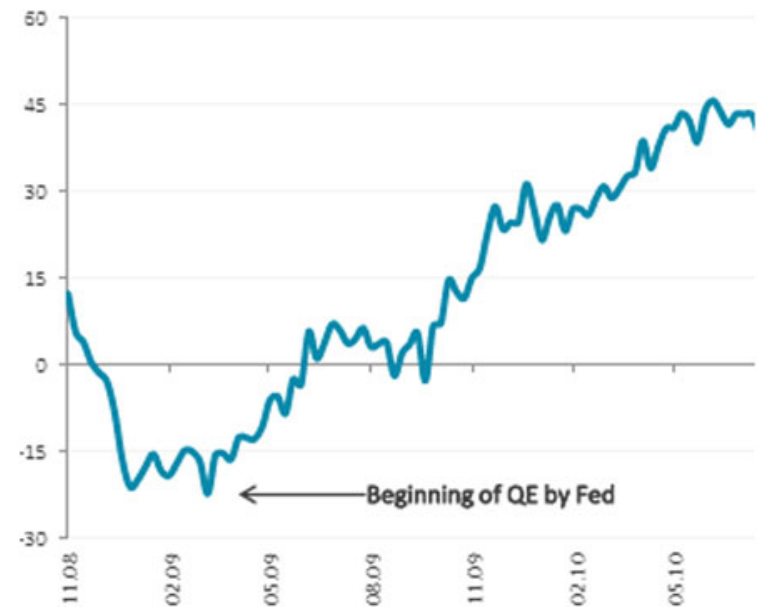

bank was implementing full-fledged inflation targeting with the interest rate as the policy tool. There are also some other institutions in the economy, such as banking supervisory and regulatory institutions. They do not have a macro perspective. They were doing microprudential activities at the individual bank level. They were looking at the individual bank's health without a macro perspective. If you look at bank-level credit growth or other variables, it seemed like there was no problem but from a macro perspective, it revealed a large current account deficit, a huge increase in credit growth and real currency appreciation, so there were some risks at the macro level. 
Fig. 9.6 Turkey: real exchange rate $(2003=100)$

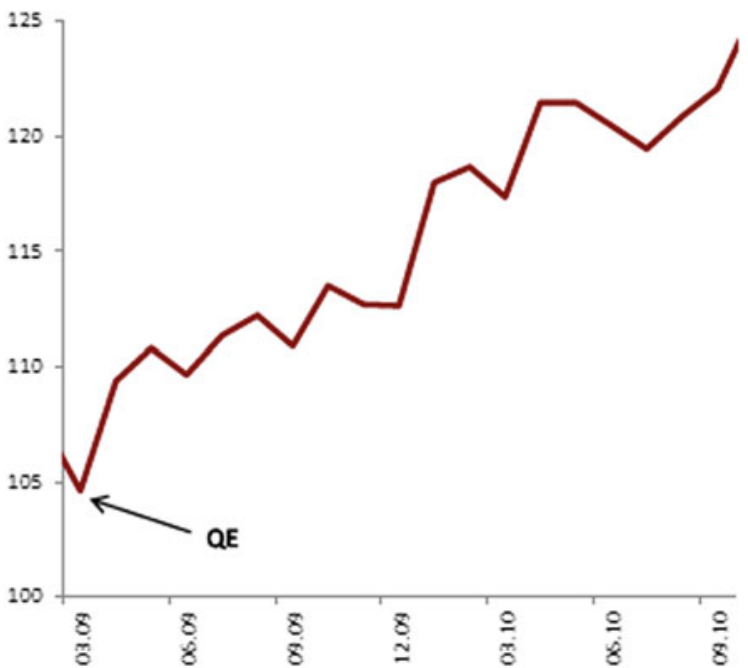

Consequently, some institutions needed to take some steps to contain the macrofinancial risks. Therefore, the Central Bank of Turkey took the first step to contain the macro-financial risks.

\section{Monetary Policy Framework}

Inflation Targeting (IT). First, the central bank had a conventional inflation targeting framework. In that framework the objective was price stability and the policy tool was the policy rate.

Monetary Policy Framework: Financial Stability Augmented IT. To contain the macro-financial risks, the central bank of Turkey changed its monetary policy framework by incorporating financial stability into the inflation targeting framework. Financial stability became one of the concerns of the central bank, while price stability remained the main objective. Since the central bank now had multiple objectives, it expanded its policy toolkit to include reserve requirement ratios and an interest rate corridor as additional policy tools.

Amplifying Effect of Capital Flows were Contained. The aim of these additional policy tools was to contain the adverse impact of capital inflows to the economy. The aim of the flexible interest rate corridor was like a capital control to decrease the capital inflows in the economy. The aim of the reserve requirements was to contain high credit growth in the economy. By changing the reserve requirements, the central bank tried to control the impact of capital inflows on credit growth rates. 
Using Monetary Policy Tools as Macroprudential Instruments. What did we do with the interest rate corridor? On the graph, there is a corridor around the one-week repo rate, which is the policy rate, represented by the black line. The aim of the corridor was to increase the volatility of short-term interest rates. During the easing of global conditions, the central bank widened the interest rate corridor downwards, which increased the short-term interest rate volatility in order to decrease capital inflows. This could be considered a capital control but the main objective of this policy was to decrease the capital inflows during that period (Fig. 9.7).

In terms of the reserve requirement ratios, before the end of 2010, there was a remuneration on the reserve requirements if the banks were paying interest on the excess reserves. After financial stability was incorporated into the monetary policy framework, the central bank stopped remuneration of the reserve requirements and increased the reserve requirement ratio by almost $10 \%$ within one year. The aim of the reserve requirement policy was to contain the increasing credit growth (Fig. 9.8).

\section{Interaction}

Participant: How was the transmission to reduce the capital flow by increasing the corridor? Usually, central banks want to make the overnight rate consistent with the policy rate. Can you explain more about how the volatility reduced capital flows? Was it through the risk channel?

Speaker: The central bank widened the interest rate corridor download, which increased the volatility in the interest rate. You are right, the interest rate was not close to the policy rate but for the central bank, the important thing was to stop the capital inflows.

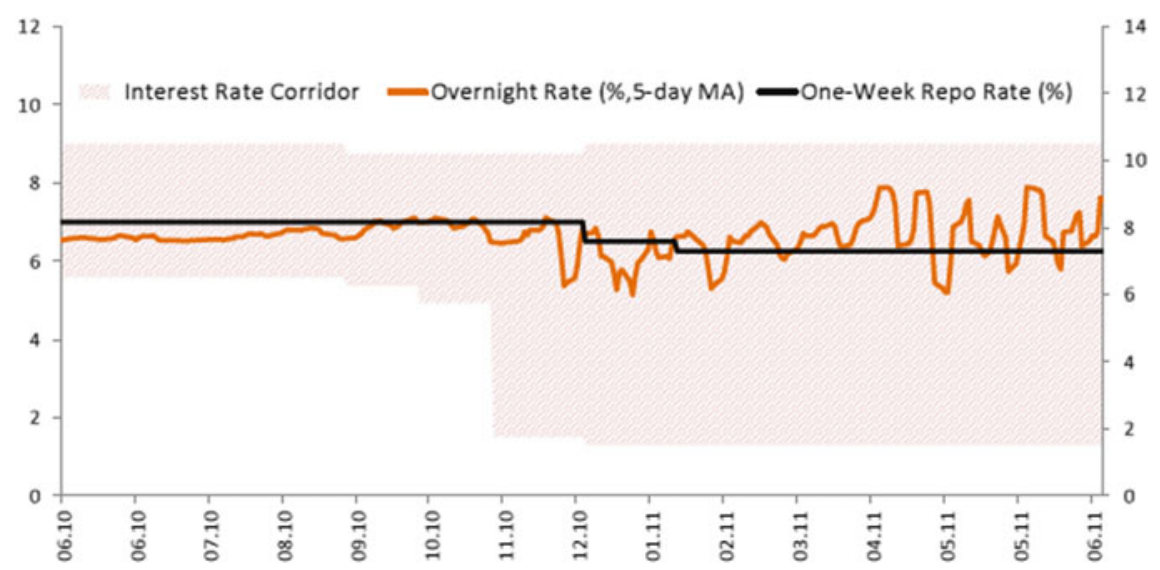

Fig. 9.7 Turkey: interest rate corridor. Source CBRT 


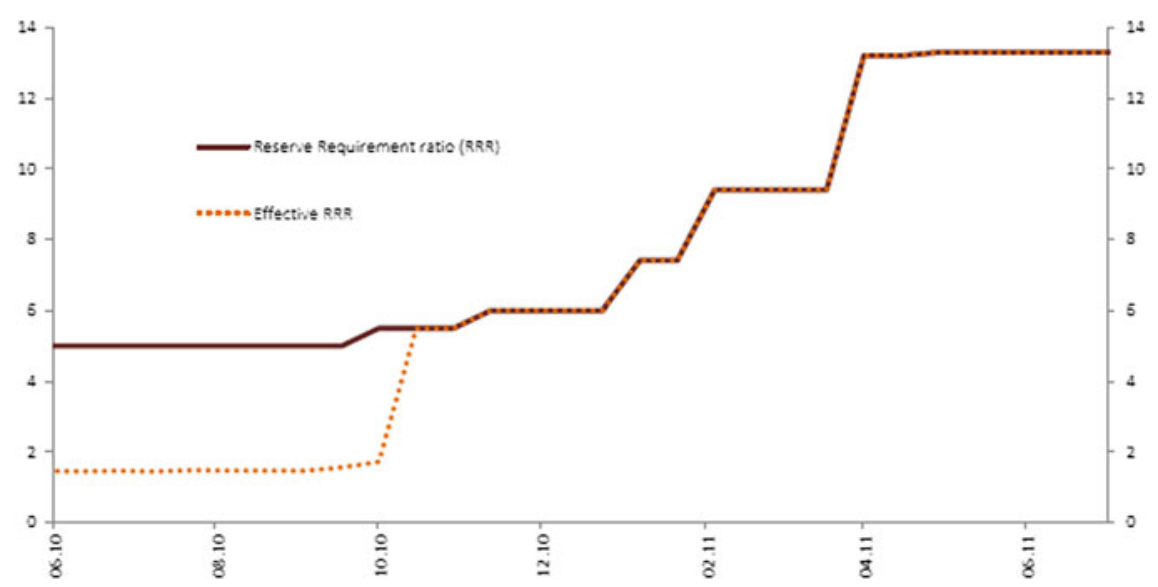

Fig. 9.8 Turkey: reserve requirement ratios. Source CBRT instrument increased the uncertainty in the financial markets.

You should not think about policy transmission, the aim of this interest rate corridor was to stop the capital inflows. The policy

Participant: What is the roof of the corridor? When we have a corridor, we have a ceiling and a lower bound so the volatility is restricted within that corridor. That is how the volatility is minimized.

Speaker: The roof of the corridor is flexible not fixed. Sometimes the corridor is wide and other times it is narrow. The width of the corridor was changed as a policy tool.

Participant: I understand that if you increase the band, the volatility will increase. I do not understand how the transmission of volatility in the one-week repo rate can hold the capital inflows.

Participant: I do not think the band is increased or decreased frequently as a matter of policy change. When you have a corridor, it means you are restricting the volatility to ensure smooth policy transmission.

Speaker: $\quad$ You are right, the volatility of the interest rate is within the corridor but when you widen the band through the lower bound, new capital flows will have low interest rates and therefore be less attractive.

Participant: Why do not you just decrease the policy rate?

Speaker: If you decrease the policy rate, credit growth will accelerate further. Our aim at the time was also to control credit growth. For that reason, we used the reserve requirement ratios. 
Communication Challenges. We implemented new policy tools, such as the reserve requirement ratios and interest rate corridor, but there were some initial communication challenges. During the conventional inflation targeting period before the global financial crisis, monetary policy decisions were communicated mainly through stable overnight interest rates and inflation. Expectations management was more straightforward as well. When we started to implement the new policy tools, we faced some communication challenges, especially within this framework. We had multiple objectives that required multiple instruments. It was hard to attach one objective to one instrument, which was a communication challenge. In addition, there was no clear definition of financial stability. For price stability, there is an inflation rate but for financial stability, there is no clear definition. This was a communication challenge for the macroprudential policies. Another challenge was the transmission channel of the new policy tools. They were new for the economy, so it was very difficult to convince the economic agents about the use of these macroprudential tools. This was another challenge for policy implementation.

\section{Interaction}

Participant: How is the independence of the CBRT set up? To whom does the CBRT report and what happens if the targets are not hit?

Speaker: To parliament. If we do not hit our targets, we must draft an accountability letter explaining why the targets were not hit. This is our accountability mechanism. We also regularly present to parliament concerning current economic conditions and developments.

Participant: I just have a quick question about the interest rate corridor. By widening the interest rate corridor, I guess you contain the capital flows, but I was wondering whether or not if there were any other unintentional effects, perhaps on bank funding strategies, for example, or loan pricing.

Speaker: There are some studies showing the banks taking the upper bound of the corridor when pricing their loans. They no longer took the policy rate as the benchmark, they were using the upper bound of the interest rate corridor. Therefore, the interest rate corridor does have an effect on loan pricing.

CBRT took some steps to manage these macro-financial linkages. At the beginning, it was very hard due to the communication challenges and uncertainty about these new policy tools, but it also created some awareness in the other financial institutions about these micro-financial risks. After CBRT took some steps to manage the macro-financial linkages, the other institution started to think the risks in a more macro-financial framework. 


\section{Financial Stability Committee (FSC): A Significant Step for a Formal Institutional Framework for MaP}

The Financial Stability Committee (FSC) was founded in 2011, consisting of five institutions, namely the CBRT, under secretariat of the Treasury, Banking Regulation and Supervision Agency, Savings Deposit Insurance Fund, and the Capital Markets Board. The aim of the FSC is to enhance information sharing, coordination and cooperation between the institutions. The main duties are to assess the systemic risks, identify necessary measures and make relevant policy recommendations to different institutions in order to increase coordination. The main aim of this committee is to increase coordination between the different financial institutions. The FSC has no decision power or tools, the power rests with the authorities represented in the Committee. Each institution still has its own mandate and responsibility but the Committee has increased coordination between the institutions. After establishment of the Financial Stability Committee, we saw a decline in long-term growth because the Banking Regulation and Supervision Agency took some LTV cap measures. It is very important to have coordination between the institutions to see the impact of macroprudential policy tools.

\section{Broad Objectives of Macroprudential Policy}

The broad objectives of macroprudential policies were to increase sustained growth prospects, contain credit growth in household over borrowing, improve the quality of external financing and bolster safety nets against external financial shocks. As I showed you previously, the current account deficit was mainly financed by short-term financial sources so one of the aims of macroprudential policy was to improve the quality of external financing, making it longer term and more stable. Another objective was to dampen the financial amplification channels. The aim of these policies was to decrease the interaction between capital flows, credit and exchange rates.

Why Focus on Credit Growth and Household Borrowing? From the literature and previous crises, credit booms are the most robust and significant predictors of financial crises. Furthermore, periods of strong credit growth are typically followed by periods of sluggish economic activity. This is true not only in Turkey, yet also in many other countries. There are many studies in the literature to support these findings. Specifically, a rise in the household debt to GDP ratio predicts lower output growth over the medium run. The main reason for using these macroprudential tools was to focus on high credit growth and household borrowing in order to contain the adverse impacts of over borrowing and excessive credit growth in the real economy.

Macroprudential Measures to Smooth the Credit Cycle and Contain Household Debt were Implemented Two Major Steps. The first round occurred in 2011, when the Financial Stability Committee was founded. Higher risk weights and provisions were 
put on consumer loans along with limits on credit card payments. Most credit card expenditure was for imported goods, so the authorities wanted to put some limits on credit card payments, especially for imported goods. In addition, the authorities also placed an LTV cap for housing loans. In the second round from 2013-2014, the caps and limits were increased, and higher risk weights were puts on credit cards. Maturity restrictions (36 months) were also introduced for uncollateralized consumer loans and an LTV cap was introduced for vehicle loans. Most recently, with the reversal of the global financial cycle, the authorities have reversed the macroprudential measures by eliminating some of the constraints on consumer loans to stimulate the real economy.

\section{What Was Achieved?}

The monetary and macroprudential policy mix in Turkey managed to engineer a soft landing and a gradual rebalancing in the economy. Furthermore, the strong link between economic activity and capital flow volatility has declined to some extent. In other words, the amplification mechanism has been contained to some extent with the help of these tools. Moreover, establishment of the Financial Stability Committee showed the importance of institutional policy coordination, which has become well understood. Well-targeted countercyclical macroprudential policies have improved the policy trade-offs faced by monetary policy. An efficient macroprudential framework requires policy coordination between different policy institutions. It was also well understood that neither monetary policy nor macroprudential policy can substitute deeper structural reforms. Turkey's vulnerabilities stemmed from structural issues, for instance savings were lower than investment thus necessitating external finance, which exacerbated the amplification mechanism between capital flows and domestic macroeconomic variables. If Turkey could reduce its demand for external financing, the country would become less vulnerable to changes in the global financial cycles. The main objective should be to unwind the vulnerabilities, which cannot be achieved long term through monetary or macroprudential policies. Structural reforms are also required. In addition, one challenge associated with the policy mix is that expectations management is much harder within a multiple-objective and multiple-instrument monetary policy framework. This is complicated further because sometimes the instruments are used in opposing directions.

\section{Interaction}

Participant: I am curious about the legal framework in Turkey. Since you added financial stability to your objective, it means you have a dual objective. Was that contained in a central bank law? Does CBRT have a dual mandate? 
Speaker: Legally, our main objective is price stability, but we also take into consideration financial stability. In the central bank law, there is no special role stipulated for financial stability. The Financial Stability Committee mostly decides the macroprudential tools. We only have the reserve requirement ratios and interest rate corridor as tools and, through the FSC, we advise the other financial institutions to apply other macroprudential measures.

We call it a macroprudential tool. The target is not the price stability objective; the target is the financial stability objective. The banks can also borrow from each other and they also come to the central bank for liquidity because interbank borrowing is insufficient. The financial markets department are using these interest rates while they are providing liquidity to the banking sector. The interbank rate is also within this corridor, which serves as a benchmark for interbank rates. This influences the banks but the aim is primarily to increase short-term interest rate volatility in order to decrease the attractiveness of capital flows. Through auctions, they change short-term interest rates within the corridor in order to decrease the attractiveness of capital flows.

Participant: What is the current loan-to-value ratio? Has it had an effect on house prices?

Speaker: $\quad$ I am not sure the current LTV ratio. It has not had an impact on house prices. The impact was on housing loans.

Participant: How frequently do you change your band? Are the loan rates pegged to the band?

Speaker: $\quad$ Not immediately. They are changing the amount of the liquidity they provide to the banking system. The banks need central bank funding because interbank funding is insufficient to meet their financial needs. They can change the band at the monthly meetings as well as the width of the corridor. They can change the funding amount to the banking system. They are just changing the amount of liquidity they provide to the banking system. Our policy rate is currently $24 \%$ because of a recent shock that triggered a huge increase in inflation. Consequently, we tightened monetary policy. We now operate a fixed corridor without changing the width of the band.

Credit Growth. In terms of what was achieved by the monetary and macroprudential policy mix, this graph shows the change in credit growth. The blue I and II indicate two rounds of macroprudential policy tightening to smooth credit growth. After implementation of two rounds of macroprudential tightening, credit growth 
was observed to decline. The aim of the macroprudential tools was to contain the consumer loans. The red line shows the change in consumer loans and the blue line shows the change in commercial loans. The impact was most significant on consumer loans. The aim was to contain the over borrowing of households and we see the impact of these macroprudential tools on consumer loans. On the other hand, commercial loans were largely unaffected (Fig. 9.9).

Current Account. In terms of the current account deficit, after implementation of two rounds of macroprudential tightening, we saw a positive impact on the current account. The graph shows a narrower current account deficit after both rounds of macroprudential tightening because we implemented some constraints on the expenditures to imported goods, similar to the consumer loans, as most of the consumer loans are going to imported goods. We saw these implications on the current account deficit as well. I do not have a graph to show how the current account deficit is financed by short-term or long-term sources, but after macroprudential tightening, most of the current account deficit was financed through long- term sources. This was another positive development for the impact of macroprudential tools (Fig. 9.10).

Reserve Requirements were used in Several Dimensions to Improve the Quality of External Finance and Bank Liabilities. To contain credit growth, we also used reserve requirements to increase the quality of external finance. Figure 9.11 shows the change in the reserve requirements for different dimensions. The top-left graph shows Turkish lira and foreign currency reserve requirement measures. We increased both the Turkish lira and foreign currency reserve requirement ratios, but the change in the foreign currency reserve requirement ratio was significantly higher than the Turkish lira reserve requirements. We also differentiated the reserve requirements for core versus non-core foreign currency liabilities of the banks. The top-right

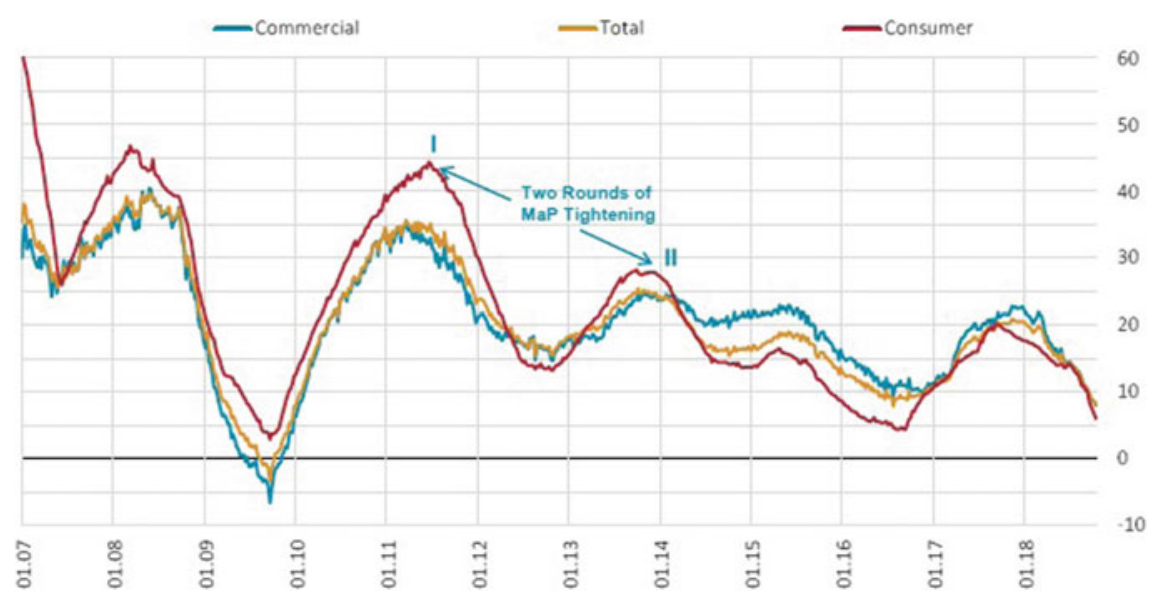

Fig. 9.9 Turkey: consumer and commercial loans (adjusted and exchange rate effect, annual percentage change) 


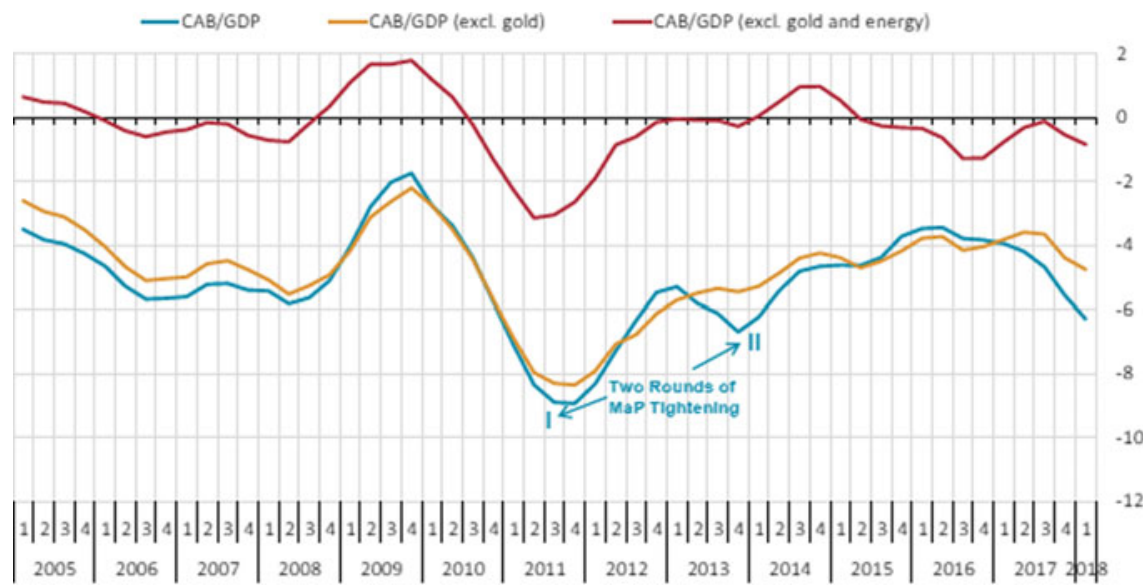

Fig. 9.10 Turkey: current account (12-month cumulative, \%GDP). Source CBRT

TL vs FX (short term)

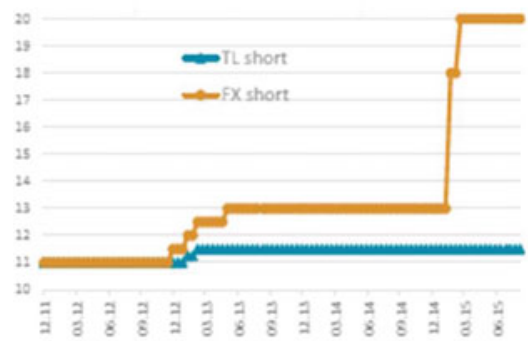

Short vs Long (core)

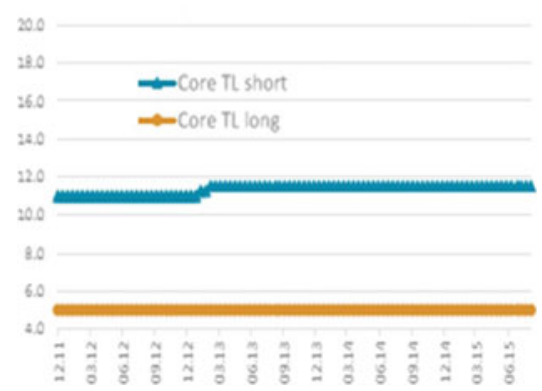

\section{Core vs Non-core (FX)}

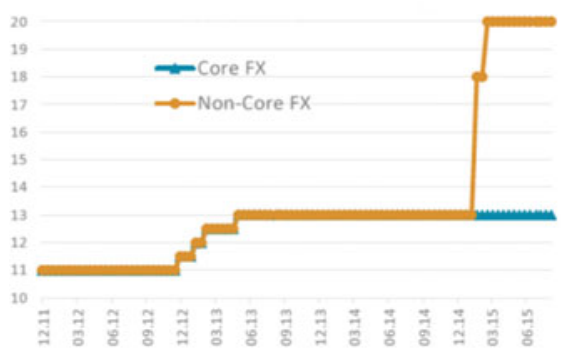

Short vs Long (non-core)

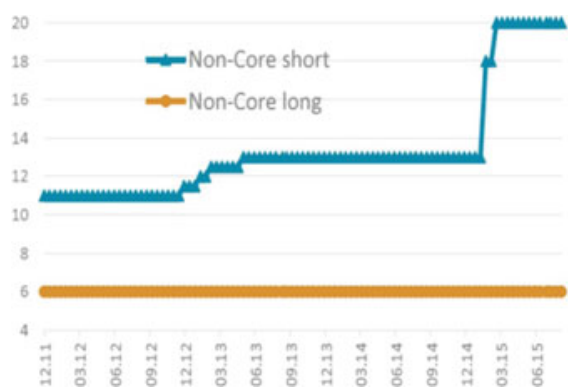

TL: Turkish Lira; FX: Foreign exchange

Fig. 9.11 Turkey: reserve requirement (based on currency). Source CBRT 
graph shows the difference between the core and non-core foreign currency liability reserve requirements. For non-core foreign currency liabilities, we implemented higher reserve requirements because we wanted to increase the quality of external finance. CBRT wanted the banks to have more stable funding, so CBRT increased non-core foreign currency liability reserve requirements more substantially than the core foreign currency liabilities. The bottom two graphs show the differentiation between the maturity-based reserve requirement measures. The left panel shows short versus long term core liability reserve requirements. We see no change in the core long-term Turkish lira liabilities. Core means deposits. CBRT wanted the banks to have stable long-term core liabilities so CBRT increased the short-term reserve requirements for core Turkish lira liabilities. The right panel shows the short versus long-term non-core liabilities. We see a similar approach here as well. CBRT wanted the banks to have long-term non-core liabilities to increase the quality of external finance so we see a huge increase in the non-core short- term liabilities of the bank. We see the impact of these different reserve requirements on the banks' foreign currency liabilities.

Maturity of Non-Core Liabilities has Improved. Figure 9.12 shows the maturity composition of foreign currency non-core liabilities. The orange dotted line shows the short-term foreign currency liabilities of the banks. The blue line shows the longterm foreign current liabilities of the banks (more than 3 years) and the red line shows the medium (1-3-year) foreign current liabilities. The measures were taken at the end of 2014 and we subsequently saw a rapid decrease in the share of shortterm foreign currency liabilities, while the long and medium-term foreign current liabilities increased after these measures were introduced at the end of 2014.

Average Maturity of Banks' External Liabilities has increased Considerably. The average maturity of the bank's external liabilities increased considerably after the measures were introduced at the end of 2014. We saw some implications on the

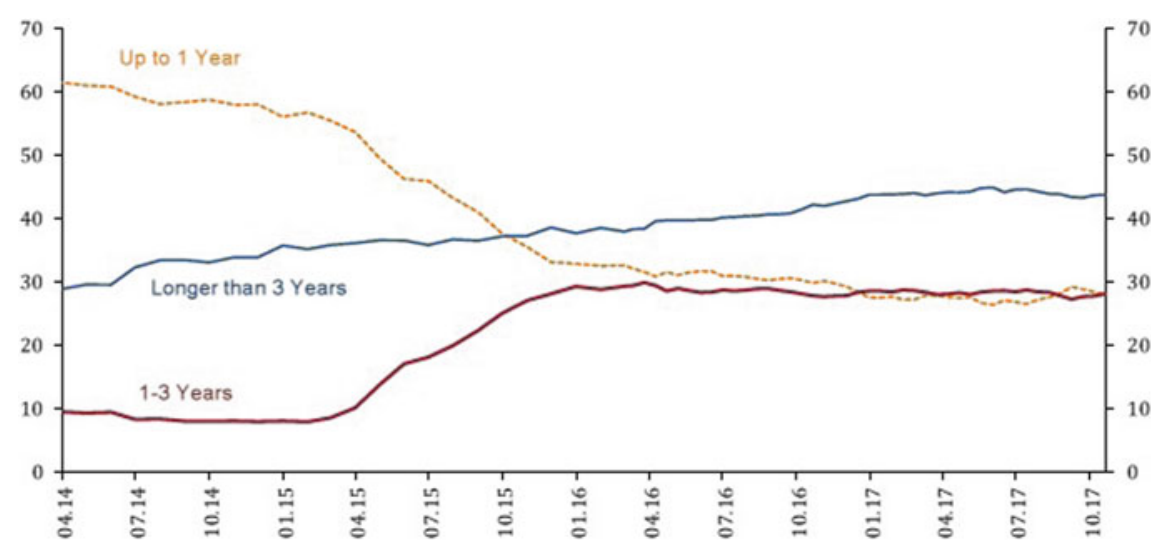

Fig. 9.12 Turkey: maturity composition of FX non-core liabilities (percentage share). Source CBRT 


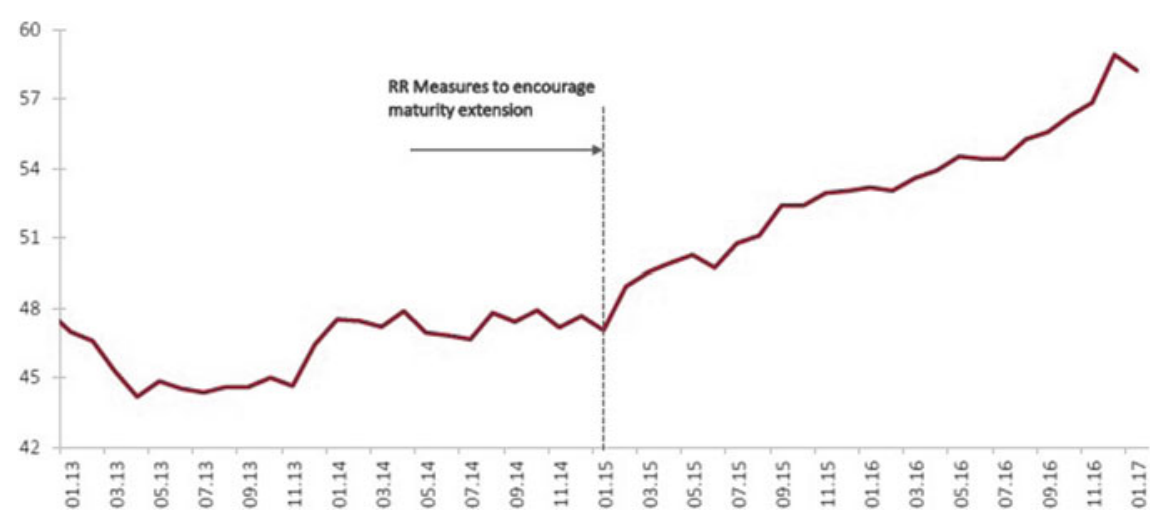

Fig. 9.13 Turkey: average maturity of non-core FX liabilities (months). Source CBRT; CMB; PDP

quality of the external finance through such differentiation in the reserve requirement measures (Fig. 9.13).

\section{Recent Developments in Turkey ${ }^{1}$}

\section{Reversal of the Global Financial Cycle}

The Turkish economy has been hit by a series of adverse events in recent years, including escalating geopolitical uncertainties, tighter global financial conditions, rising protectionism, higher oil prices and a deterioration in bilateral relationships with some of Turkey's traditional partners. The Federal Reserve has stopped quantitative easing policy and started to normalize monetary policy, which has led to a reversal of the global financial cycle. The series of adverse events have led to a further deterioration in risk sentiment, weaker external flows and exchange rate depreciation pressures. There has also been a huge sell-off of Turkish assets.

Relative Value of Turkish Lira. The blue line shows the value of the Turkish lira, the orange line is the average value of emerging economies' currencies and the red line shows the relative value of the Turkish lira. In 2017, there has been a huge depreciation of the Turkish lira due to a series of adverse events. During the few months from May to August 2018, the Turkish lira depreciated by almost $50 \%$ before subsequently rebounding. There was huge uncertainty during that period and we see the implications of that in the exchange rate, while other emerging markets enjoyed more stable exchange rates (Fig. 9.14).

\footnotetext{
${ }^{1}$ Up Until 2018.
} 


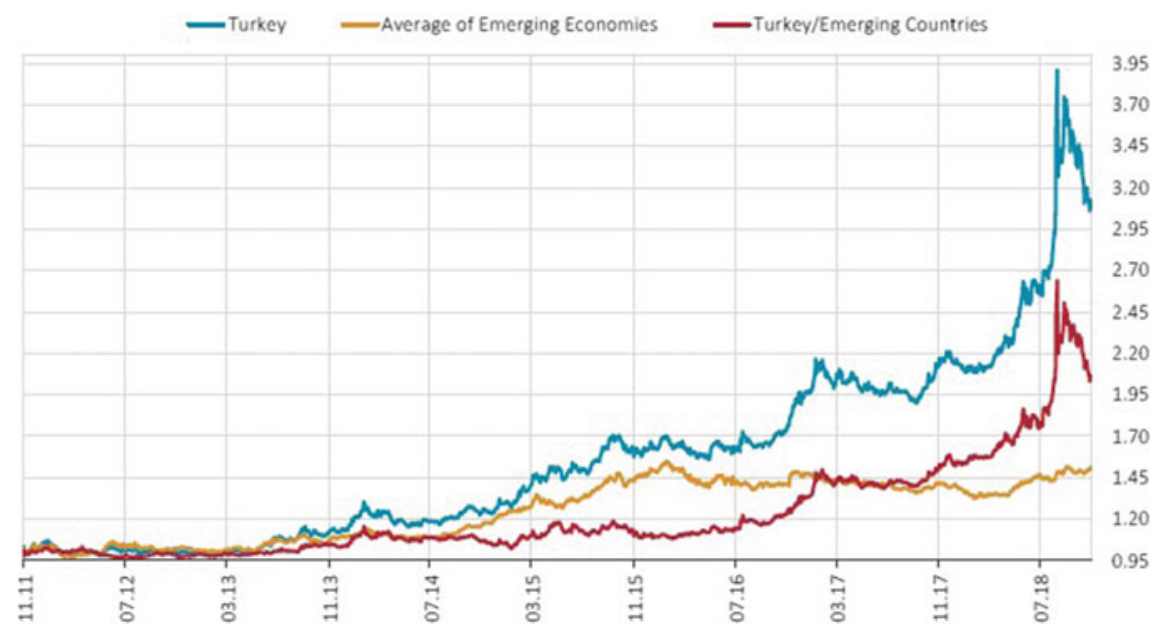

Fig. 9.14 Turkey: relative performance of Turkish Lira against USD $(01.11 .2011=1)$. Source CBRT

Aggregate Demand. Since financial market uncertainty increased during that period, we also see implications in terms of aggregate demand. Financial market uncertainty and exchange rate uncertainty negatively affected aggregate demand. Banks were also less eager to lend in the uncertain environment, which also undermined aggregate demand.

CPI and Core Inflation. The decrease of aggregate demand also had an impact on inflation. Exchange rate pass-through is very high in Turkey, however, so the exchange rate shock fed through to a huge and rapid increase in inflation. Furthermore, the uncertainty also led to an increase in terms of exchange rate pass-through. The pricing behavior of economic agents was also negatively affected because they did not know what would happen to the domestic currency in the subsequent periods. Therefore, expectation formation and expectation management were also adversely affected during this period of turmoil and we see it reflected in inflation (Fig. 9.15).

\section{Reversal of the Global Financial Cycle and Gradual Normalization of Monetary Policy}

CBRT has formulated an integrated approach since 2016 to achieve and maintain low and stable inflation. CBRT has pursued price stability-oriented monetary policy, complemented by simplifying the monetary policy framework. Volatility in the central bank funding rate has been gradually reduced and, as of June 2018, the one-week repo rate was restored as the policy rate of CBRT (a single policy rate) instead of the interest rate corridor. There is still an interest rate corridor but its 


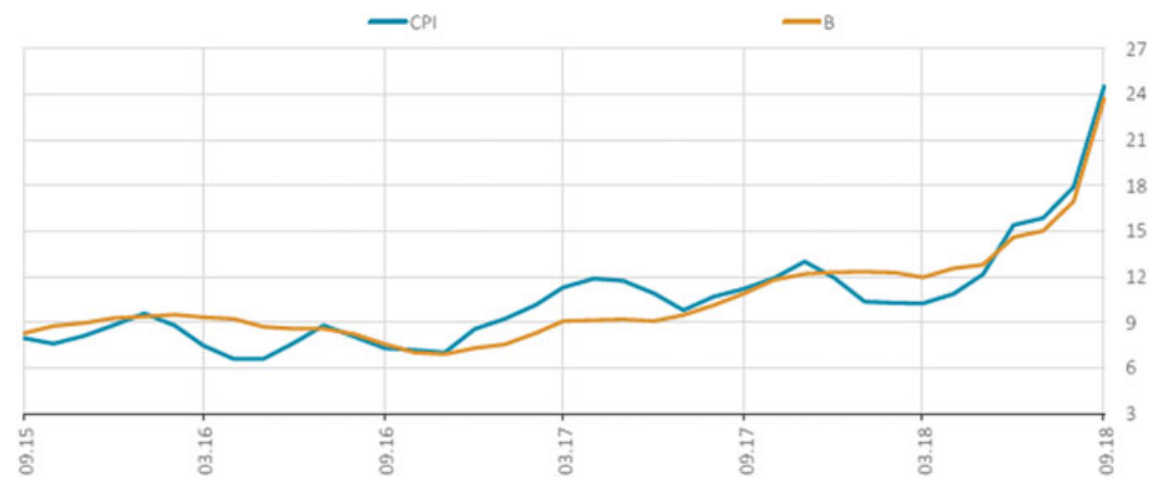

Fig. 9.15 Turkey: CPI and core price index (B) (annual, \% change). Source CBRT; TURKSTAT

width is fixed. CBRT also identifies structural impediments to disinflation, while promoting a coordinated effort among all relevant institutions to address further challenges, particularly related to changes in global risk sentiment. To minimize the adverse impact of huge uncertainty and exchange rate shocks, CBRT first implemented frontloaded and pre-emptive monetary tightening, which prompted exchange rate appreciation. CBRT also implemented some Turkish lira and foreign currency liquidity measures by easing reserve requirement policies due to huge uncertainty when the banks required liquidity. Therefore, the central bank provided liquidity by easing the reserve requirements for the banks. CBRT also made rediscount credit and swap arrangements due to the uncertainty surrounding foreign currency.

\section{Macroprudential Measures}

The Financial Stability Committee has also taken some measures in response to less accommodative global liquidity conditions by reversing macroprudential tightening in terms of consumer loans. The maturity of consumer loans was also increased, while decreasing the limits on consumer loans. The FSC also implemented a twopillar approach to contain risks emanating from FX borrowing by non-financial corporations. A decree was issued, effective from May 2018, that requires firms with less than a USD15 million credit balance to maintain sufficient foreign currency revenues to meet their current FX debt, targeting SMEs because there was a huge increase of foreign currency in the domestic currency. If a firm had a foreign currency loan after the exchange rate shock, it was very difficult to repay the foreign currency liabilities. For larger non-financial corporations, CBRT implemented more effective balance sheet monitoring. CBRT has been constructing a timely, standardized and detailed database of firms' foreign currency exposures that includes currency and maturity-based foreign currency liabilities and assets. The data is collected on a quarterly basis. 


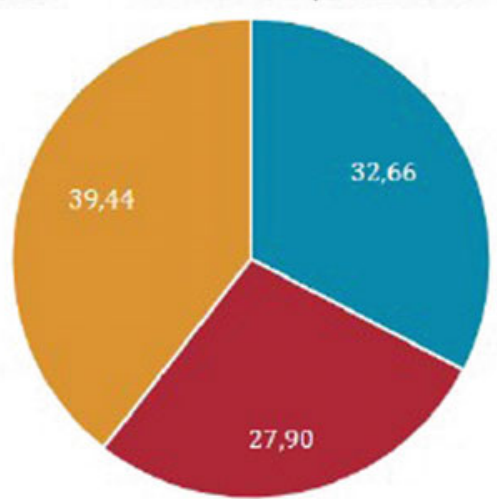

Fig. 9.16 Turkey: indebtedness and leverage ratios of non-financial companies listed on BIST (\% share). Source FINNET; Public Disclosure Platform

Financial Liabilities of Corporate Sector at Reasonable Levels. The financial liabilities of the corporate sector are now at reasonable levels. Figure 9.16 shows a reasonable level of indebtedness and leverage ratios of non-financial companies listed on BIST.

Released Data Points to a Halt in the Contractionary Trend in the first quarter of 2019. There have been positive signs in terms of credit growth, with data pointing to a halt in the contractionary trend. We saw an increase in credit growth in the first quarter of 2019.

\section{Concluding Remarks}

Central banks have a large number of instruments and many tools to deal with spillovers from large capital flows, exchange rate volatility and credit booms but the Turkish experience highlights some challenging aspects regarding policy design, namely to decide which measures would best target the risks at the source in a timely manner without knowing the real transmission mechanism. In addition, macro-financial stability requires multiple instruments to achieve multiple intertwined targets, which necessitates effective coordination amongst policy institutions. Policy actions require a comprehensive perspective from all shareholders to assess potential externalities and avoid possible unintended consequences. Given the highly integrated international financial markets, domestic policy designs need to take into account possible spillovers from changes in external funding conditions. 


\section{Interaction}

Participant: Is the inflation rate is the impact of Turkish lira depreciation or a supply-side effect? In terms of setting annual economic growth, which institution in Turkey is responsible for setting the annual economic growth target?

Speaker: It is mostly the depreciation of the Turkish lira because the exchange rate pass-through is very high in Turkey and there was huge uncertainty at that time, so the pricing behavior of the economic agents was negatively affected. Therefore, they reflect the rapid change in the exchange rate to prices, not supplyside driven. We can think of it from a supply-side perspective because there are many imported goods in the price index, but it was mostly exchange rate driven. Regarding your second question, the Ministry of Finance publishes a yearly program, setting the growth targets within that program.

Participant: Do you have any special policies to deal with your high current account deficit? In terms of the exchange rate pass- through and large current account deficit, do you have any special policies to deal with that?

Speaker: They are trying to contain the imported expenditures. We use macroprudential tools to control the current account deficit by containing the imported expenditures but we do not have a specific tool. They are working on structural policies to create more value-added exports but we do not have any special tools.

\section{Empirical Study}

In this session, I will explain some research at CBRT about macroprudential policy implementation. I will discuss some studies on macroprudential policy implementation in Turkey. The first paper I will present is about global liquidity and the impairment of local monetary policy transmission. It tries to understand why we need macroprudential policies and the impact of global liquidity conditions on domestic monetary policy transmission. The second paper I will present is about the transmission mechanism of reserve requirement ratios. The title of the paper is Reserve Requirements, Liquidity Risk and Bank Lending Behaviour. The last paper is about systemic externalities due to risky foreign currency loans, which explores the impact of risky foreign currency borrowing on the banks' lending behavior after a currency depreciation shock. The name of the paper is Foreign Currency Risk, Systemic Externalities and Real Effects. 


\section{Why Turkey?}

Turkey has been quite active in its use of macroprudential policies in recent years, applying a wide range of tools to impose restrictions on both borrowers and financial institutions. The design and implementation of the macroprudential policy framework in Turkey reflects a purely emerging economy perspective, where special emphasis has been given to the role of capital flows.

\section{Global Liquidity and the Impairment of Local Monetary Policy Transmission $^{2}$}

We are still working on this paper and welcome any comments and feedback. In this paper, our question is how global liquidity conditions impair local monetary policy transmission. This paper is about the interaction of global liquidity conditions, local credit markets and domestic monetary policy. How do global liquidity conditions affect local monetary policy transmission? For instance, the central bank implements a tightening policy by increasing the interest rate in order to tighten economic conditions and increase economic activity. If the global liquidity conditions encourage the banks to borrow from foreign lenders, they will not implement the change in domestic monetary policy to their own loan rates. This leads to a decline in the efficiency of local monetary policy transmission. Therefore, we have tried to understand how these global liquidity conditions impact domestic monetary policy transmission.

\section{Motivation}

There has been a dramatic increase in international financial linkages over the last few decades. There is also a large debate in the literature over the ability of local policymakers to steer their domestic financial conditions in the face of huge capital inflows. In this paper, we try to understand to what extent global liquidity conditions affect the strength of domestic monetary policy transmission. We are trying to understand the impact of global liquidity conditions on the bank lending channel of monetary policy. The monetary policy authority sets the policy rate, which the banks take into account in their lending behaviour because an increase in the policy rate increases the banks' funding costs, with implications on credit supply and lending rates. In the literature, there are many papers looking at how banks react differently depending on their ability to insulate their loan portfolios from changes in monetary policy, including bank capital, liquidity and size. Do larger banks with more capital and liquidity react differently to banks with different characteristics? We also

\footnotetext{
${ }^{2}$ Fendoglu et al. (2019).
} 
included the global liquidity exposure dimension to these characteristics. A bank is exposed to global liquidity conditions if it has more foreign currency non-core liabilities, such as borrowing from the wholesale market in a foreign currency. We are trying to understand if these banks have different lending behavior compared to less exposed banks after local monetary policy tightening.

We are also looking at the risk-taking channel of monetary policy. By risk-taking channel, we mean that does looser monetary policy encourage commercial banks to extend credit to riskier firms because the easier liquidity conditions help the banks to take more risk. We look at how bank lending and the risk-taking channel may differ for domestic monetary policy in an emerging market economy.

Another motivation for this paper is to understand how global liquidity conditions affect local credit market conditions. We are trying to understand three interactions. Local monetary policy is set and one of the aims is to influence local credit market conditions, but global liquidity conditions have an impact on this transmission mechanism. The mechanism is through carry trade after local monetary policy tightening since the banks that are more exposed to global liquidity are able to borrow more from abroad. If global liquidity conditions are easier, they reflect less the change in the local monetary policy conditions to their loan rates because they are able to borrow more from abroad so they do not require central bank funding. Consequently, local policy tightening will be less effective under these conditions. Since changes in local monetary policy do not have an effect on foreign lending rates, it creates a carry-trade mechanism for the banks, which is the underlying mechanism. Our paper provides sharper identification and inferences for these channels.

\section{Data}

We use Credit Registry data from Turkey to answer these questions. Credit registry data is micro-level supervisory data that contains very important information, such as which bank is lending to which firm, how much, at which rates and maturity as well as the collateral of such loans, risk provisions and so on. Credit registry data is very valuable. In the literature, many papers are using credit registry data in their analyses. Credit registry data encompasses the universe of corporate loans granted by all banks operating in Turkey, with unique lender and borrower identifiers, interest rates, loan outstanding, currency of the nomination, maturity, collateral property, cash versus non-cash, loan origination and termination dates and loan risk rating. This is very detailed granular information.

We studied the period from January 2006 to December 2016, looking only at local (domestically-owned) banks, with a sample of 20. We exclude foreign banks from our analysis because foreign banks can borrow from their headquarters if there is a local monetary policy tightening. The impact is seen on locally-owned domestic banks. There are a total of 881,606 firm-month observations. We categorize eight loan types, including domestic versus foreign currency, short $(<1$ year) versus long-term, collateralized versus non-collateralized. 


\section{Empirical Strategy: Identification}

Identification is based on firms that borrow from multiple banks with different levels of reliance on global liquidity. We use the variation in the banks' reliance on global liquidity because different banks have different access to global liquidity. We use this variation in access to global liquidity in our analysis. We look at the impact on similar types of loan, such as the same currency of the nomination or similar maturity and collateral properties. We also explore whether firms switch banks after a local policy tightening. We did this for the robustness analysis.

\section{Empirical Framework}

Baseline. The empirical framework in this project was to look at the impact of variations in banks' exposure to global liquidity on their lending behavior. In this regression, the dependent variable is the interest rate on a loan that bank $b$ provides to firm $f$ with type $a$ at time $t$. The important coefficient for us is this interaction coefficient with the change in the domestic monetary policy and the foreign funding ratio of the bank. The foreign funding ratio of the bank is a measure of the bank's exposure to global liquidity. If a bank is more exposed to global liquidity, it has a higher foreign funding ratio. Therefore, we try to understand how these types of bank, that have more access to global liquidity, change their lending rates in response to an increase in the monetary policy rate. We also look at whether banks with a higher foreign funding ratio react differently to other banks. In our regressions, we also have a bunch of controls for domestic economic conditions, such as domestic economic activity indicators, exchange rate and monetary policy rate. We also added a bunch of controls for firms' demand in our regressions.

Global Liquidity versus Transmission. For the impact of global liquidity on transmission, we also added global liquidity indicators into our regressions as an interaction variable. For the global liquidity indicators, we used VIX as a benchmark indicator for global liquidity. An increase in the VIX implies a tightening in global liquidity conditions. We also use the Federal Reserve balance sheet size, US monetary base or the Shadow Federal Funds Rate as global liquidity indicators. We also checked if our results were robust to these alternative global liquidity indicators. The main question that we want to answer is whether easier global liquidity conditions make globally funded local banks set lower loan rates after a domestic monetary policy tightening? And, does it differ for risky and non-risky firms?

Risk-Taking. We also analyze the risk-taking behavior of the banks. We interact the firm risk indicator variable with the foreign funding ratio of the banks and the monetary policy interaction. The firm risk indicator is an indicator variable of whether a firm has defaulted ex-ante on any loan at a bank prior to borrowing at time $t$. Our hypothesis is that banks with a higher degree of reliance on global liquidity raise 
their lending rates less for ex-ante risky firms following a domestic monetary policy tightening.

In the literature, most papers are looking at the impact of easier monetary policy on risk-taking behavior but in our case, we are looking in an alternative way by observing the impact on bank risk-taking when there is local monetary policy tightening.

In this regression, we also add interactions of monetary policy with other bank controls, such is the size of the bank, the liquidity ratio of the bank and the capital ratio of the bank.

\section{Results}

Bank Reliance on Global Liquidity and Transmission. I did not put a results table here, I have only included the benchmark results. The regression results show that banks with higher reliance on global liquidity set their loan rate 29 bps lower than a bank with a lower reliance on global liquidity after a cumulative $100 \mathrm{bps}$ increase in the monetary policy rate (for a given firm). In other words, as domestic monetary policy is tightening, banks are raising their lending rates but if a bank is more exposed to global liquidity and, therefore, able to borrow from a foreign bank or financial market, it would raise its lending rate less than a bank with less borrowing from abroad. That is the baseline result. The table shows the interaction coefficients for different bank characteristics. From the table, the most important bank characteristic is the foreign funding ratio. The impact of other bank characteristics is insignificant and the economic impact is less than the foreign funding ratio.

Global Liquidity versus Transmission. Is the banks' planning behavior different under different liquidity conditions? From the triple interaction, we see that when $\log$ (VIX) is lower, namely that global liquidity conditions are easier, banks with higher reliance on global liquidity raise their loan rates by 36 bps less than banks with a lower reliance after a cumulative $100 \mathrm{bps}$ increase in the domestic monetary policy rate (for a given firm). From the table, we see the impact of policy tightening on the loan rate is highest in terms of the foreign funding ratio under different global liquidity conditions.

Bank Reliance on Global Liquidity and Risk-Taking. For a given ex-ante risky firm, banks with higher reliance on global liquidity raise their loan rate by 10 bps less than a bank with lower reliance, after a cumulative $100 \mathrm{bps}$ increase in the monetary policy rate. This means that if a bank is more able to borrow from abroad, it will show more risk-taking behavior after local monetary policy tightening because the bank has greater access to foreign funds so it can take more risk and lend more to riskier firms.

This effect is higher when global liquidity conditions are easier. When $\log$ (VIX) is lower by one standard deviation, banks with higher reliance on global liquidity raise their loan rate to a risky firm by 40 bps less and to a riskless firm by 35 bps less compared to banks with a lower reliance, after a cumulative 100 bps increase in the domestic monetary policy rate. A risky firm means a firm that has previously 
defaulted on a loan. If global liquidity conditions are easier, banks behave with risky and riskless firms in a similar way. Easier global liquidity conditions exacerbate this behavior.

\section{Interaction}

Participant: Concerning the regression itself, I see that you take up to 3month lags. What is the reason for this? Foreign funding is a binary variable? Is it continuous? You have presented it as high versus low so I am wondering if there was a threshold?

Speaker: The data is monthly and the impact is quarterly, so there is a 3month lag. Foreign funding is a bank characteristic, expressed as a function of non-core liabilities to total liabilities. It is a continuous variable, changing over time. There is no threshold, it is continuous over time.

\section{Mechanism: Data (Carry Trade)}

Regarding the mechanism, we showed that banks exposed more to global liquidity conditions set lower rates compared to less exposed banks after a local monetary policy tightening because they are able to borrow more from abroad. We showed that banks with more exposure to global liquidity conditions tend to borrow more after a local monetary policy tightening. To show this mechanism, we use a different database showing cross-border lending through micro-level data. In the database, we see which local bank is borrowing from which foreign bank in which currency as well as the amount and so on. We use this dataset to see whether after a local monetary policy tightening, the banks with ex ante more exposure to global liquidity borrow more. In this dataset, we also see the jurisdiction in which the foreign bank is located as well as its headquarters. We control this information in our analysis to control for the supply side. We ran a regression to see how these banks with a high foreign funding ratio change their cross-border borrowing after a local monetary policy tightening. We added the interaction between local monetary policy and the foreign funding ratio of the bank with a bunch of controls for the supply side. The dependent variable is quarterly change in the logarithm of domestic bank $b$ 's volume of (or the cross-border interest rate on) borrowing in currency $c$ from the global bank subsidiary $g$ whose headquarters is in country $h$. The question we want to ask from this regression is whether domestic banks demand more funds from abroad after a local policy tightening?

Our regression showed that following domestic monetary policy tightening, local banks with higher foreign funding borrow (demand) more funds from abroad. Since we do not have any impact on foreign interest rates, after a local monetary policy tightening, the banks have a relatively lower interest rate for foreign funding, which 
creates a carry trade mechanism for the banks. Consequently, as the local monetary policy tightening does not have any impact on foreign interest rates, which leads to carry trade, the banks borrow more from abroad after a local monetary policy tightening.

\section{Conclusion}

Our paper shows that easier global liquidity strongly attenuates the transmission of a tightening of local monetary policy rates on bank loan rates. This creates looser credit standards for banks with higher reliance on global liquidity. In terms of the risktaking channel, we found that globally funded local banks set lower rates for ex-ante risky firms following a local policy tightening. The main mechanism of these results is the carry trade, with globally funded local banks borrowing more from abroad after policy tightening. This demonstrates a need for macroprudential policy actions to enhance monetary policy transmission because the banks that are more exposed to global liquidity conditions do not reflect the change in the domestic monetary policy. Therefore, to increase the effectiveness of local monetary policy transmission, we need macroprudential actions. When we extrapolated the results to when global liquidity cycles and domestic monetary policy are synchronized, the results became insignificant. We see that macroprudential tools help to strengthen monetary policy transmission when global liquidity conditions are easier. This provides positive evidence for the use of macroprudential tools when the global liquidity cycle is stronger to enhance local monetary policy conditions.

\section{Interaction}

Participant: You said that carry trade increases when the VIX increases. Intuitively, it should not be like that. It should be more correlated with LIBOR or the bond market. It seems to me that the foreign banks are somehow going into the derivative market to get the loans. Maybe you could share how macroprudential policy actions would help in this case.

Speaker: $\quad$ The derivative markets are off-balance sheet items so this could not be explored.

Participant: I think this is great research and a very interesting presentation. You are using very big panel data with millions of variables for the estimation. There is an assumption, however, of symmetry between monetary policy tightening and loosening. I feel there is some differences between the two and perhaps you could separate monetary policy tightening and loosening.

Speaker: $\quad$ I agree, we need to check if there is an asymmetric effect of local monetary policy tightening and loosening and what the impact 


\begin{tabular}{|c|c|}
\hline & $\begin{array}{l}\text { is of global liquidity conditions on the easing and tightening of } \\
\text { domestic monetary policy. }\end{array}$ \\
\hline Participant: & $\begin{array}{l}\text { Are there any bank regulations to hedge against foreign } \\
\text { funding? Do you also differentiate between the type of owner- } \\
\text { ship of the bank, for example foreign banks or local banks? }\end{array}$ \\
\hline Speaker: & $\begin{array}{l}\text { There are some regulations. If there is an open FX position } \\
\text { (more FX liabilities than FX assets) on the balance sheet, the } \\
\text { bank is required to hedge using off-balance sheet items, such as } \\
\text { derivatives or swaps. Furthermore, the open FX position must } \\
\text { not exceed a certain threshold of the bank's equities. There is a } \\
\text { regulation that the open FX position has to be less than } 5 \% \text { of } \\
\text { total equity. In Turkey, we have many foreign and state-owned } \\
\text { banks but in this analysis we only used locally-owned banks } \\
\text { and state-owned banks, the foreign banks were excluded from } \\
\text { our research. }\end{array}$ \\
\hline Participant: & $\begin{array}{l}\text { Do you know how your results compare with the literature in } \\
\text { terms of what you found and the coefficients? }\end{array}$ \\
\hline Speaker: & $\begin{array}{l}\text { There are no papers that look at the impact of foreign funding } \\
\text { ratios on local monetary policy tightening but there are other } \\
\text { papers that look at other bank characteristics, such as size, } \\
\text { capital and so on, which we also included in our regressions. We } \\
\text { do have results consistent with the existing literature on those } \\
\text { kinds of bank characteristics. }\end{array}$ \\
\hline Participant: & $\begin{array}{l}\text { You only look at the Federal Reserve's balance sheet. Is that } \\
\text { because most of the funding comes from the United States and } \\
\text { not from Europe? Could you perhaps look at the ECB's balance } \\
\text { sheet? What would happen to your results using the ECB's } \\
\text { balance sheet? I am not sure of the characteristics of where } \\
\text { the funding comes from. }\end{array}$ \\
\hline Speaker: & $\begin{array}{l}\text { We used these measures of global liquidity indicators because } \\
\text { they are the most commonly used indicators in the literature. } \\
\text { The Federal Reserve's balance sheet is the main driver of global } \\
\text { liquidity and also US monetary policy is the same. We just } \\
\text { followed the literature. You are right though, nowadays the ECB } \\
\text { is still implementing QE policy, whereas the US Federal Reserve } \\
\text { has already stopped. Our sample ends at the end of 2016, so for } \\
\text { now it is okay but we should take into account other advanced } \\
\text { economies' balance sheets as well. }\end{array}$ \\
\hline Participant: & Have you included Islamic banks as well? \\
\hline Speaker: & $\begin{array}{l}\text { We did not include Islamic banks because they have a different } \\
\text { structure. }\end{array}$ \\
\hline
\end{tabular}


Table 9.1 A hike in the reserve requirement ratio and bank balance sheet

\begin{tabular}{l|l|l|l}
\hline \multicolumn{2}{l|}{ Before a hike in RR } & After a hike in RR \\
\hline Assets & Liabilities & Assets & Liabilities \\
\hline Loan: 90 & Deposits: 100 & Loan: 90 & Deposits: 100 \\
\hline Unencumbered securities: 10 & Repo: 0 & Unencumbered securities: 5 & Repo: 5 \\
\hline Encumbered securities: 0 & & Encumbered securities: 5 & \\
\hline Reserves: 0 & & Reserves: 5 & \\
\hline
\end{tabular}

Source Alper et al. (2018)

\section{Reserve Requirements, Liquidity Risk and Bank Lending Behavior $^{3}$}

The second paper is about reserve requirements, liquidity risk and bank lending behavior, published last year in the Journal of Money, Credit and Banking. I would like to briefly explain their findings.

\section{Motivation}

Following the global financial crisis, the size and volatility of capital flows into emerging market economies have increased substantially. This has created financial and macroeconomic stability challenges for emerging market economies, such as keeping policy rates at low levels in order to avoid excessive appreciation of domestic currencies, while engaging in macroprudential tightening to curb rapid credit growth. Therefore, reserve requirements have been one of the most commonly used tools among unconventional monetary policy instruments. This paper looks at the empirical evidence for the transmission channels of reserve requirements, identifying a new channel (liquidity channel), which works through the availability of liquid assets.

Table 9.1 shows an example balance sheet of a bank, showing the impact of a change in the reserve requirements. Before an increase in the reserve requirement, on the asset side, we suppose the bank has a loan of 90 Turkish lira and 10 unencumbered securities. Therefore, the total assets of the bank is equal to 100. On the liability side, the bank has deposits totaling 100 Turkish lira. After the change in reserve requirements, however, the bank maintains deposits totaling 100 Turkish lira but the bank must meet the increase in the reserve requirement by increasing repos to 5 because it was unable to immediately increase its deposits. By increasing the repos, the securities portfolio changed, with unencumbered securities decreasing to 5 and encumbered securities increasing to 5 . In addition, the reserves also increased to 5 . Consequently, the asset side of the balance sheet has increased from 100 to 105 . Since the bank could not immediately change its loan- lending behavior, it changed

\footnotetext{
${ }^{3}$ Alper et al. (2018).
} 
its funding from the central bank to finance the additional financing needs of the hike in the reserve requirement. Therefore, the change in the repo part necessitates a change in the portfolio of securities. The bank decreased its unencumbered securities because they need to pledge some of their securities to be able to fund themselves from the central bank because they are using the securities as a guarantee, while they are funding themselves from the central bank. To fund themselves more from the central bank, they decrease their unencumbered securities and increase their income securities. In this study, the bank liquidity measure is calculated as the ratio of unencumbered government securities as a fraction of total liabilities. A bank with a higher liquidity ratio can handle changes in the reserve requirements by pledging their unencumbered government securities. The liquidity channel that the researchers are trying to understand is a hike in the reserve requirement, leading to more bank borrowing from the central bank by pledging collateral, which declines the liquid assets ratio of the banking system and the banks would subsequently tighten their lending behavior.

\section{Liquidity Channel: Reserve Requirements and Funding from CBRT}

The mechanism works in this way. This graph shows short-term funding from the central bank as a share of total liabilities as a black line and the reserve requirements held by banks as a share of total liabilities as a dotted line. From the graph, it is clear that after the reserve requirement ratio was increased, bank funding from the central bank also increases. Banks increase their funding from the central bank after reserve requirements are increased.

\section{Liquidity Channel: Liquid Assets, Reserve Requirements and New Loans}

We also see that the securities held by the banks decreased after the reserve requirements have been increased. The dotted line shows reserve requirements as a share of total liabilities, the dashed line shows new loans as a share of total liabilities and the solid black line shows securities as a share of total liabilities. After the reserve requirements were increased, banks held fewer securities on their balance sheets, pledging them to collateral, and also decreased new loans.

\section{Liquidity Channel}

According to the liquidity channel theory, deposits and central bank borrowing are assumed to be imperfect substitutes but most studies in the literature assume they are perfect substitutes. The researchers assume deposits and central bank borrowing 
are imperfect substitutes because central bank borrowing/funding contains interest rate risk due to its short-term nature that is subject to changes in monetary policy. A tightening of local monetary policy would increase the funding cost, therefore, but if the bank holds deposits, the interest rate is predetermined and not as sensitive as funding from the central bank. The bulk of the existing literature not only assumes perfect substitutability but considers the transmission mechanism of reserve requirements through the traditional cost channel, namely that an increase in the reserve requirements represents an additional tax on deposits. On the other hand, the liquidity channel takes into account the composition of the securities of the banks as an impact of changes in the reserve requirement.

\section{Data}

Bank-level data is used for the sample period from June 2010, when macroprudential policy tools were first used, until December 2015. The researchers use the ratio of required reserves maintained with the CBRT against banks' deposits and other selected liabilities. The paper looks at the impact of Turkish lira (TL) denominated loan rates, with the impact on commercial and consumer loan rates explored separately). The central bank primarily used the reserve requirements for TL-denominated liabilities for countercyclical purposes. The liquidity ratio was calculated from the total securities held by bank $i$ as a fraction of its total TL liabilities.

\section{Empirical Analysis}

They ran several regressions at the bank level. The dependent variable is the interest rate on commercial or consumer loans of bank $i$ in month $t$. The explanatory variables on the right-hand side are the lagged loan rate, monetary policy rate, central bank overnight lending rate or the average funding rate in month $t$. The central bank uses an interest rate corridor, so the average funding rate takes into account the differences in the funding cost in this interest rate corridor, while the CBRT overnight lending rate tends to be fixed at the upper bound of the interest rate corridor. Another explanatory variable is the monthly percentage change in the USD/TL exchange rate. The authors control for changes in the exchange rate. In order to test the liquidity channel, the authors add interactions of the bank liquidity ratio with the reserve requirement ratios. If a bank is more liquid, with a higher liquidity ratio, it would be less affected by changes in the reserve requirement ratios. To understand this impact, the authors also added interactions between the bank liquidity ratio and the reserve requirement ratios. 


\section{Results}

Regarding commercial loan rates, columns $1-4$, the overnight lending rate has a positive impact on commercial loan rates. When there is an increase in the central bank's overnight lending rate, namely when there is an increase in the upper bound of the interest-rate corridor, commercial loan rates tend to increase. For the reserve requirement ratios, we see that when there is an increase in the reserve requirement ratios, commercial loan rates tend to increase for these types of banks. If there was perfect substitutability between central bank funding and deposits, the reserve requirements would not be significant, but we see a positive and significant coefficient for the reserve requirements in these regressions.

Liquidity Channel. In terms of the liquidity channel, the authors also interact the reserve requirement ratio with the liquidity ratio of the bank. We see in Column 3 that the reserve requirement still has a positive impact with a negative coefficient for the interaction variable. This means that for a given increase in the reserve requirement ratio, if a bank has a higher liquidity ratio, its increase in the lending rate will be less. If a bank has higher liquid assets, it will be more able to handle a short-term increase in the reserve requirement ratios. Therefore, the impact on its lending rates will be less. The final two columns show the impact on the consumer loan rate and deposit rate. For the consumer loan rate, the authors use the average funding rate because there is some research at the central bank that shows the average funding rate is more influential for consumer loan rate pricing. Therefore, the average funding route is used and similar results were found but the liquidity channel is insignificant for the consumer loan rate. For the deposit rate, however, the liquidity channel is significant with a negative coefficient for the deposit rate.

\section{Conclusion}

In conclusion, this study explores the interaction between reserve requirements, bank balance sheets and bank lending behavior in the context of Turkey. The authors show that the quantitative policies of the central bank affect lending behavior and the liquidity position of the banking system. The consequent shift in bank liquid assets is associated with a significant change in bank lending behavior. The study found that banks with a stronger liquidity position are less sensitive to changes in RR ratios. Overall, the results lend support to the view that reserve requirements have the potential to be an additional tool for the central banks in emerging market economies to relieve the policy trade-offs posed by the volatility of capital flows. 


\section{Foreign Currency Risk, Systemic Externalities and Real Effects $^{4}$}

\section{Motivation}

Capital flows to emerging market economies may be beneficial by financing productive investment and fostering financial deepening but may also sow the seed of financial vulnerabilities in the event of a sudden reversal through financial integration, and especially after the Asian financial crisis, we see excessive foreign currency borrowing as well as real consequences in the economy. This paper tries to understand the systemic externalities due to foreign currency risk. We look at a period of sharp depreciation, after which hedged borrowers are unable to service their foreign currency debt. This will adversely impact the banks' capacity to lend, while simultaneously negatively impacting the firms. Even if they do not have any foreign currency liabilities, the banks will no longer be able to provide loans as their foreign currency borrowers are unable to repay the loan, thus undermining bank lending capacity. Risky foreign currency lending has received attention within policy circles. Several chapters of the IMF Global Financial Stability Report are dedicated to risky foreign currency lending. The European Systemic Risk Board has also pointed out several risks associated with foreign currency lending, especially in Hungary where there is a huge amount of foreign currency lending. The research provides well identified, micro-level evidence for this mechanism.

Figure 9.17 shows what the paper is trying to understand. The green nodes show healthy institutions and red nodes indicate unhealthy institutions. A risky foreign exchange borrower does not take into account that its risky borrowing may adversely affect other borrowers through banks after a sharp exchange rate depreciation and similarly, for a bank lending to risky firms. This provides a basis for the use of FX-related macroprudential policies.

\section{Our Question}

Do systemic externalities due to risky FX loans matter for credit supply dynamics after currency depreciation? The paper uses micro-level data for identification, taken from the Turkish Credit Registry and CBRT Company Accounts database. The paper takes an exogenous and sharp domestic currency depreciation period during the global financial crisis from October 2008 to October 2009. We define a firm as a risky FX borrower if it has more short-term FX credit than exports. The short-term FX credit is a foreign currency liability. As a natural hedge, a firm might have foreign currency assets as exports but if it has more foreign currency liabilities, it will be more exposed to currency depreciation and the firm is said to be riskier. We calculate the weighted average exposure of each bank to risky FX borrowers because we see

\footnotetext{
${ }^{4}$ Fendoglu et al. (forthcoming).
} 
Fig. 9.17 Bank's debt structure

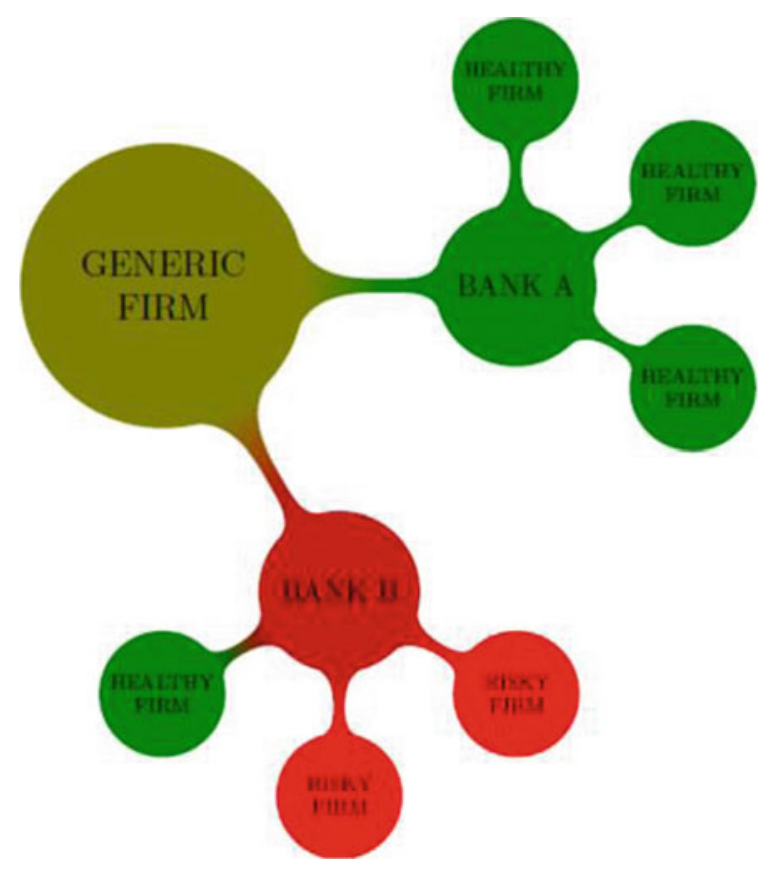

from the credit registry which firm is borrowing from which bank at which maturity and which amount. In this paper, the identification is a given firm borrowing from at least two banks with different ex-ante exposures to risky FX borrowers. Do credit supply dynamics differ across these banks? Banks with more exposure to riskier firms are cutting their loans more after currency depreciation and we are trying to look at differentiation in terms of bank exposure to riskier firms. We also looked for any binding effect at the firm level on bank credit supply because firms can switch between banks.

\section{Data}

We use Credit Registry data from Turkey, which contains extensive details on bankfirm loan-type level loan transactions. The sample period is from October 2008 to October 2009, encompassing 60,000 firms and 23 banks (excluding Islamic and development banks, which apply different lending structures). We matched the Credit Registry data with the Company Accounts Database using annual balance sheets and the income statements of a large sample of firms exceeding 10,000 for the period from January 2006 to December 2016. The coverage exceeds $96 \%$ of outstanding FX loans in October 2008. We controlled for the banks characteristics in our analysis using the Supervisory Bank Database from the Banking Regulation and Supervision Agency as well as the monthly balance sheets and income statements of banks. 


\section{Definition: FX Risk}

Firm risk is defined by how much a firm can meet its short-term FX bank credit by its exports. A higher value implies a higher risk firm. Bank exposure to risky FX borrowers is the weighted average of these ratios at the bank level. This means that if a bank is working predominantly with riskier firms, the bank would also be more exposed to the risk of a currency depreciation shock. We calculated bank exposure at the bank level by using the firms' riskiness. Banks that extend more credit to riskier firms are potentially more exposed to a currency depreciation shock. We calculate and measure the shocks ex ante. We will see the impact of a shock by using the ex-ante variation in the banks' exposure to riskier FX borrowers.

\section{Interaction}

Participant: How did you define the weight?

Speaker: The weight is defined from the credit registry data, showing which firm is borrowing from which bank. For each firm, we calculate the weight in the bank's loan portfolio multiplied by the firm's riskiness to get a bank level of exposure to risky borrowers.

\section{Empirical Model}

How do banks adjust their supply of credit in response to sharp depreciation? Does exposure to risky FX borrowers matter? We ran a regression for our analysis. The dependent variables include the log change in outstanding credit from October 2008October 2009. The explanatory variable is the exposure to riskier borrowers and we also added some other bank controls, such as non-core FX liabilities, tier-1 capital ratio, liquidity ratio, size, NPL and ROA. If a firm is always borrowing from one type of bank, they may have a different lending relationship, so we controlled for that as well by adding the share of bank $b$ 's credit in firm $f$ 's total bank credit. As a dependent variable, we also look at lending behavior at the extensive margin. By extensive margin, I mean that the banks that are more exposed to riskier borrowers are giving new loans to new borrowers or new firms or are they terminating their existing relationship? We also look at the impact on this extensive margin behavior of the banks.

Banks working more with ex-ante risky FX borrowers reduce their credit supply more. The dependent variable in this table is the change in the amount of credit from a bank. The explanatory variable is the exposure to risky FX borrowers and the other bank controls. We add some controls one-by-one in each column and the most saturated control is in the last column (6). We see that for the estimations of all regressions, the coefficient of exposure to risky FX borrowers is negative, which means that if a 
bank is working with riskier firms, after currency depreciation, such a bank would cut their lending more to an average firm. Even if an average firm does not have any foreign currency loan, through the banking system they will have fewer loans due to the riskier foreign currency lending by the banks.

Ex-ante risky FX borrowers are more likely to default in the future. The banks are cutting their lending to average firms because the riskier firms are unable to pay back their loans. The dependent variable in this table shows the future default as an indicator variable. If a firm defaults on a loan within the next year, it receives a value of 1 . No default gives a value of 0 . We ran the dependent variables on the firm's characteristics. 'Firm FX Risk' means that the firm has an open FX position. We control for the firm size, age, net worth and exports. We see that if a firm has a higher open FX position, it would be more likely to default within the next year after a currency depreciation shock. Therefore, ex-ante risky FX borrowers are more likely to default in the future.

Banks working more with ex-ante risky FX borrowers have higher NPL later. For that reason, banks working with more ex-ante risky FX borrowers have a higher increase in their respective NPL ratios. The y-axis shows change in the bank NPL ratio and the $\mathrm{X}$-axis shows bank exposure to risky FX borrowers. As a robustness check, we also use a different measure for exposure to risky FX borrowers. In the baseline case, we use the firms' short-term foreign liabilities as a foreign currency liability but for a robustness check, we use total foreign currency credit. For both cases, we see that if a bank is working more with risky firms, after a currency depreciation shock they show a higher increase in their respective NPL ratio.

Banks working more with ex-ante risky FX borrowers are more likely to terminate their relationship with existing clients. This table shows the results at the extensive margin for the amount of loans these banks are giving. The results demonstrate that banks working more with ex-ante risky FX borrowers are more likely to terminate their relationship with existing clients. We could not find any significant impact on the lead lending behavior of these types of banks.

The reduction in bank credit is binding (firm-level). Firm-level regressions showed that the reduction in bank credit is binding because the firms are unable to switch between banks. The declining credit, therefore, is binding at the firm level.

\section{Conclusion}

We found some robust evidence for systemic externalities through the banking system following an exchange rate depreciation shock. We saw a binding reduction in overall bank credit supply due to risky FX borrowers and binding financial constraints for firms. The firms are unable to switch from risky to less risky banks. A key insight is that an optimal policy design should pay attention to such externalities/spillovers. Exante prudential policies should make borrowers/lenders internalise such externalities. 


\section{References}

Alper, K. et al., 2018. Reserve Requirements, Liquidity Risk and Bank Lending Behaviour. Journal of Money, Credit, and Banking, 50(4), pp. 817-827.

Fendoglu, S., Gulsen, E. \& Pedro, J.-L., 2019. Global Liquidity and the Impairment of Local Monetary Policy Transmission. CBRT Working Paper Series, Volume 1913.

Fendoglu, S., Gulsen, E. \& Pedro, J.-L., n.d. Foreign Currency Risk, Systemic Externalities and Real Effects. CBRT Working Paper Series, Volume Forthcoming.

Open Access This chapter is licensed under the terms of the Creative Commons AttributionNonCommercial-NoDerivatives 4.0 International License (http://creativecommons.org/licenses/bync-nd/4.0/), which permits any noncommercial use, sharing, distribution and reproduction in any medium or format, as long as you give appropriate credit to the original author(s) and the source, provide a link to the Creative Commons license and indicate if you modified the licensed material. You do not have permission under this license to share adapted material derived from this chapter or parts of it.

The images or other third party material in this chapter are included in the chapter's Creative Commons license, unless indicated otherwise in a credit line to the material. If material is not included in the chapter's Creative Commons license and your intended use is not permitted by statutory regulation or exceeds the permitted use, you will need to obtain permission directly from the copyright holder.

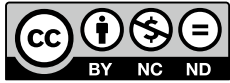

